\title{
Quantitative Easing, Global Banks and the International Bank Lending Channel
}

\author{
Carmela D’Avino ${ }^{a, 1}$ \\ ${ }^{a}$ Royal Docks School of Business and Law, University of East London, Water Lane, London, E15 4LZ, \\ UK. Email: $\underline{\text { C.Davino@uel.ac.uk }}$
}

\begin{abstract}
The current debate on the international transmission of shocks generated by quantitative easing (QE) programmes mainly focuses on the impact on financial markets' yields and returns. This paper adds to the literature by investigating the existence of an international bank lending channel activated by QE, focusing on the behaviour of US global banks. In particular, the empirical analysis explores the impact of the Federal Reserves' QE policy on lending of foreign branches of US banks. The findings reveal significant policy-induced liquidity spillovers via foreign lending by US global banks during the QE policy implementation in the US, suggesting the existence of an international bank lending channel. This channel worked its way through different segments of the credit markets, depending on the relative importance of host countries. Overall, our findings highlight the role of global banks in channelling QE-created liquidity across borders, adding pressure to increasing debt levels in foreign countries.
\end{abstract}

Keywords: Quantitative easing, Global banks, International shocks transmission.

JEL codes: E50, F33, F34, F60, G01, G21.

Funding: This research did not receive any specific grant from funding agencies in the public, commercial, or not-for-profit sectors.

\footnotetext{
${ }^{1}$ Acknowledgements: I would like to thank the editor and two anonymous reviewers whose constructive and insightful comments helped to greatly improve this manuscript.
} 


\section{Introduction}

Unconventional monetary policy adopted by the Federal Reserves (Fed) following the collapse of Lehman Brothers featured large-scale purchases of Treasury and Agency debt securities from non-bank sectors in the secondary markets. By expanding the central banks' balance sheet, this type of quantitative easing (QE) policy has allowed the Fed to inject liquidity into the economic system via the creation of bank reserves (Bernanke and Reinhart, 2004) ${ }^{2}$. QE in the US lasted almost six years in a three-stage chronological implementation: from December 2008 until March 2010 (QE1), from November 2010 until June 2011 (QE2 - phase 1), from October 2012 until October 2014 (QE2 - phase 2). Overall, it involved the purchase of \$3.5tr worth of securities resulting in an unprecedented expansion of banks' excess reserves, which reached $\$ 2.4$ tr.

To date, research has primarily focused on evaluating the effects of the unconventional monetary stimulus on domestic and foreign financial markets' yields and returns and macroeconomic volatility (Ahmed and Zlate, 2014; Barroso et al., 2015; Borio, 2011; Chen et al., 2012; Mallick et al., 2017). The portfolio rebalancing channel has been identified as the key transmission conduit through which this type of QE policy feeds through the real economy (Bernanke and Reinhart, 2004; Blinder, 2010; Gagnon et al., 2011). Underpinned by the assumption of imperfect substitutability between money and financial securities, this channel is activated by private sector agents who, in response to lower long-term yields on assets repurchased by the central bank, turn to the purchase of other higher-yielding assets, such as corporate bonds and equities (Brunner and Meltzer, 1973; Tobin, 1969) ${ }^{3}$. The portfolio rebalancing channel can reach beyond national borders. Brana and Prat (2015) for instance find that excess global liquidity intensified by widespread implementation of unconventional monetary policies have spilled over emerging economies' financial markets resulting in asset prices inflation. With particular reference to the US, Fratzscher et al. (2016) show that the second wave of QE has led to financial imbalances in emerging countries due to excessive liquidity build-up and the consequent pressure on asset prices, yields and currencies.

\footnotetext{
${ }^{2}$ As argued by Blinder (2010), an alternative form of QE is when by central banks exchange short-term for longterm financial assets. This type of unconventional policy changes the asset composition of the central bank balance sheet rather than the size.

${ }^{3}$ Other possible transmission channels of QE work through variations in expectations, see Joyce et al. (2012) for a detailed discussion. Also, Krishnamurthy and Vissing-Jorgensen (2010) identify a number of risk premia channels.
} 
Only limited attention has been paid to assessing whether the QE has worked its way through the economy via the bank lending channel (BLC), shifting the supply of credit granted by banks ${ }^{4}$. The existence of a domestic bank lending channel activated by unconventional monetary policy is confirmed in the work by Bowman et al. (2011) for Japan, Garcia-Posada and Marchetti (2016) for Spain and Rodnyasky and Darmouni (2017) for the US. In particular, Rodnyasky and Darmouni (2017) find that the last wave of the QE programme in the US led to an increase of domestic commercial banks' lending by 3\%. Still, the existence of an international BLC activated by unconventional monetary policies, involving banks shifting their supply of loans abroad in response to QE, remains largely unexplored in the literature.

This paper aims at filling this gap by investigating the international spillovers of QE through a BLC activated by US global banks, which were heavily involved in the intermediation of large volumes of asset repurchase transactions, crediting customers' deposits accounts while expanding their excess reserves holdings. Joyce et al. (2012) argue that the amplification of a BLC attributable to QE programmes is dependent upon the nature of the newly created deposits, other than the health of banks ${ }^{5}$. If these are mainly short-term flighty wholesale deposits, then, the QE will not operate via a BLC as refinancing uncertainty would reduce banks' willingness to extend new loans due to precautionary reasons. The BLC instead is activated when the newly created deposits are kept within the banking system as term or saving deposits, i.e. the QE liquidity is not reinvested in financial markets. Butt et al. (2014), for instance, show that in the UK QE did not operate via a BLC exactly because of the flighty nature of the deposits created by the programme. The observed volatility in deposits supports the existence of a portfolio rebalancing channel as large proportions of newly created bank deposits were used to finance high yielding securities. The investigation of the existence of an international BLC activated by the QE programme in the US is motivated by the observed expansion in global operations of domestically headquartered banks witnessed in the recent years coupled with the increase in domestic time deposits and interoffice outflows.

The focus on the international dimension of the BLC is here also justified by the high degree of globalisation of US banks. These latter have been found to transmit shocks across the borders by actively managing their liquidity on a worldwide basis via transactions in internal capital markets (Cetorelli and Goldberg, 2012). Narrowing domestic interest margins

\footnotetext{
${ }^{4}$ Joyce and Spaltro (2014) suggest that this gap in the academic debate may be due to the presumption that the deleveraging of banks during financial distress leads to a freeze of bank lending even in a liquidity-abundant environment (see for instance Gambacorta and Marquez-Ibanez, 2011).

${ }^{5}$ It is referred to as bank funding channel in their paper.
} 
in conjunction with active internal capital markets might have stimulated US global banks to channel the increased domestic deposit base to foreign countries via their foreign branches.

International spillovers of $\mathrm{QE}$ through credit expansion in foreign countries, i.e. an international BLC, remain broadly unexplored in the literature. A notable exception is the paper by Morais et al. (2015) in which the authors show that the significant presence of US and EU banks' foreign affiliates in Mexico increased credit supply to local firms during the QE implementation period in the US. Liu and Pogach (2017) show that there is a complementarity between domestic and foreign lending of US global banks, implying that policy-induced liquid abundance at home is likely to increase foreign lending via foreign offices. The authors, however, do not explicitly explore the extent to which the US-based QE programme has increased foreign lending of US global banks. This paper contributes to the literature by extending the findings by Morais et al. (2015) providing a more comprehensive account of the effect of QE on the foreign operations of banks worldwide, focusing on US global banks. An ad-hoc dataset is used for this intent which contains balance sheet data of foreign branches of US banks by country of location, available from the Federal Financial Institutions Examination Council (FFIEC). Dynamic panel regression analysis is employed with the aim to analyse lending trends of foreign offices of global banks in their host locations in response to the QE policy in the US.

Overall, the findings reveals the existence of an international bank lending channel during the QE policy implementation in the US activated by global banks. In particular, the transmission of US-generated liquidity shocks across the borders has asymmetric impacts on the lending of foreign branches. In host-countries where foreign branches of US banks have larger activities, US QE significantly increased local loans secured by real estate and commercial loans. In international and offshore financial centres and in those host-countries where foreign branches have smaller activities, an international BLC was activated via interbank markets as local interbank lending increased in response to the QE programme in the US.

Our findings have interesting policy implications. Global banks by reallocating liquidity across borders via internal capital markets may reduce the impact of the unconventional monetary policy on domestic lending. Also, the reallocation across the borders of QE liquidity via the banking system can have important repercussions on recipient countries' level of debt and asset prices. As argued previously, existing literature acknowledges the inflationary pressure on assets prices following QE policies in third countries due an international portfolio rebalancing channel. An international BLC activated by global banks 
may contribute to increasing debt levels in foreign countries impairing local monetary policymakers' objectives and financial stability. Foreign branches of banks headquartered abroad comply with the financial regulation of the country where their parent is located. Still, in the event of an increase in local systemic risk or financial instabilities due to rising debt levels following large liquidity inflows into local credit markets via foreign banks, local regulators can resort to product-based macroprudential regulation on credit limit. The latter applies to all financial institution operating in a particular jurisdiction. That is, timely and welltuned macroprudential regulation in recipient countries may contain eventual undesired pressure on local debt markets due to third countries' QE-generated liquidity spillovers via international banking.

The paper is organised as follows. Section 2 provides an overview of the dynamics behind the existence of a BLC following QE as well as some stylised facts in support of the existence of an international BLC activated by US global banks. Section 3 presents the econometric methodology adopted and section 4 discusses the results. Section 5 presents and discusses the robustness checks and section 6 concludes.

\section{The bank lending channel, international spillovers and QE}

\subsection{BLC and $Q E:$ An overview}

The credit view of the monetary policy transmission mechanism describes shocks propagation through the economy arising from variations in external finance premium, that is, the difference between the external and internal costs of funding faced by borrowers (Bernanke and Blinder, 1988; Bernanke and Gertler, 1995). The bank lending channel implied within this view refers to the amplification of monetary shocks by banks arising from an impairment in their funding capability due to rising external finance premium. The main assumption underpinning the BLC is the existence of credit market frictions, mainly in form of asymmetric information, which weaken the banks' ability to raise non-reservable funding when a monetary policy contraction reduces demand deposits. The contraction in lending witnessed in the economy can then be explained by both a reduction of loan demand caused by traditional interest rate channels drivers and loan supply caused by banks hilting their liquidity creation.

The empirical relevance of this channel has been repeatedly questioned in the past two decades as institutional changes in financial systems have eased the access to alternative nonreservable sources of funds. Some scholars, on the other hand, argue that no matter how easily 
a bank can find alternative source of funding, a BLC would still subsist due to the higher cost of non-deposits borrowings (Bernanke, 2007; Disyatat, 2010; Stein, 1998).

Unconventional monetary policy can activate or amplify the BLC depending on the public's willingness to reinvest QE money. In particular, as shown by Butt et al. (2014), the BLC can arise from QE to the extent to which extra deposit funding translates into stable deposits, i.e. time and savings. Fig. 1 shows a stylised balance sheet of an economy with only one representative bank and the effect that the QE has on its balance sheet over a three-period horizon. In $\mathrm{t}=0, \mathrm{QE}$ has not been implemented yet and the bank has total assets amounting to $\$ 200$. The bank has a large share of claims in the form of long-term loans, worth $\$ 150$, and the remaining assets have shorter maturity and are bundled together as 'other assets'. On the liability side, debt is raised via demand deposits plus wholesale funding and term deposits. Liabilities are segmented in this way to disentangle the flighty, i.e. demand deposits and wholesale funding, from the non-flighty, i.e. term deposits, funding components. For simplicity, required reserves and capital are not considered in this stylised example.

Fig. 1. QE and BLC for a representative bank

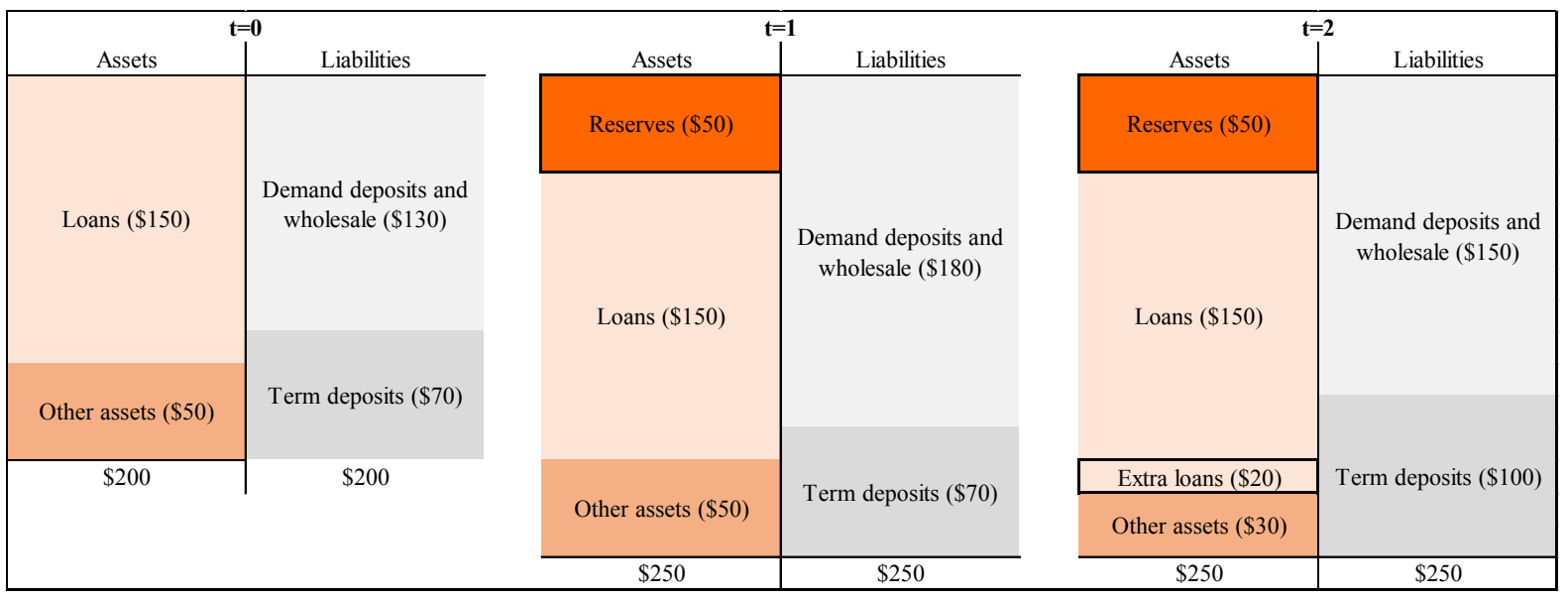

In $\mathrm{t}=1$ the central bank implements the QE policy (middle panel of Fig. 1) purchasing the equivalent of $\$ 50$ in securities from the private sector. The bank intermediates this transaction by crediting the demand deposit of the private agents by $\$ 50$ which is matched with an increase in (excess) reserves by $\$ 50$. Overall, the bank's balance sheet has increased by the amount of the QE transaction, i.e. \$50, affecting only the demand deposits held at the commercial bank on impact. The right-hand panel of Fig. 1, i.e. in $\mathrm{t}=2$, are shown the conditions under which a BLC exists. It is here assumed that part of the demand deposits, in this case $\$ 20$, is used by the private sector to purchase other high yielding securities, and kept in the form of 
demand deposits in the system, while the remaining $\$ 30$ is placed in term deposits. Comparing the balance sheet at $\mathrm{t}=2$ versus that in $\mathrm{t}=0$, the liability structure of the banks has changed and features a higher proportion of term deposits. This may lead banks to be more willing to extend loans replacing shorter term assets with longer term loans equal to, say, \$20. In this way, also the asset composition will be altered by the QE. The eventual unwinding of QE in the medium term will drain the excess reserves and reduce the wholesale funding under the pre-condition of the existence of an external financial premium.

\subsection{An international BLC in the US? Some stylised facts}

In the US the effect of QE on domestic lending has been rather limited. As showed by Rodnyasky and Darmouni (2017) the effect on domestic loan supply by banks resulting from the $\mathrm{QE}$ programme was 3\% at most, with important cross-sectional variations across banks for some of which the observed growth rate of loans was notably lower. These modest growth rates in domestic lending were witnessed notwithstanding the increase in the stable deposit base during the QE period. Fig. 1.a (appendix) shows that long-term deposits of the private sector held at US banks, that is savings and small time deposits, have experienced a structural break in their trend, increasing notably since late 2008. At the same time, the ratio of loans and leases to long-term deposits has fallen steadily, stabilising only towards the length of the sample.

This puzzling evidence can be explained by the US banks' willingness to expand foreign, rather than domestic, lending. Foreign lending of US banks has indeed stretched out at an unprecedented scale since the start of the QE programmes, supporting the plausibility of an international BLC. Narrowing domestic net interest margins may partly explain the increase in foreign loans provisions by US banks: in most of the countries in which US global banks have a large presence via their branches lending rates are higher than US ones, as shown in Fig.2.a. Domestic and foreign lending behaviour of US banks have indeed depicted somewhat different trends in the post-crisis QE era, i.e. December 2008 - October 2014. Outstanding domestic loans in the US have stagnated especially during the 2010-13 period, whilst picking up at a rather fast rate only from 2014 onwards (Fig 3.a, appendix). Over the period 2008q4 $2014 q 4$ local claims of foreign offices of US banks have increased by over 55\%, expanding by over \$600bn (Fig.4.a). This evidence is in stark contrast with trends of international banking observed globally. As pointed out by Forbes et al. (2017) the post-crisis era is characterised by a de-globalisation of banking, especially as far as international capital flows are concerned. While unconventional monetary policies implemented in several parts of the world have 
resulted in a retrenchment of cross-border flows, this does not seem to be the case for lending of foreign offices in the case of US global banks.

The observed expansion in foreign credit has been coupled with a decrease in geographical dispersion of foreign banking activities of US global banks. The number of host countries in which US banks have assets in excess of $\$ 250 \mathrm{~m}$ has decreased from over 70 before the crisis to 40 at the end of 2013. Nonetheless, the loans extended by these entities has grown at a remarkable rate since late 2009 (Fig. 5.a).

Further support to the presumption that part of the extension in foreign credit may have been financed with QE-created liquidity in the US is advanced in Fig. 6.a (appendix) which shows that the three waves of QE policy implementation were matched with a surplus in net interoffice accounts of US banks resident domestically vis-à-vis their foreign affiliates. This constitutes a shift from the historical trend that sees US-located banks having largely negative net interoffice positions (assets minus liabilities) with affiliates located abroad.

\section{Econometric model}

\subsection{Data and estimation strategy}

The foreign branch report of condition (FFIEC 030 report) is compiled by the FFIEC with the intent to monitor foreign operations of US banks. Within this report, foreign branches of US-chartered banks with assets in excess \$250 million disclose rather segmented balance sheet data. The frequency of reporting is dependent on the size of operations of the branch: quarterly for operations in excess of $\$ 2$ billion and annually otherwise ${ }^{6}$. Although branch level reports are confidential, balance sheet data of foreign branches aggregated by host country can be obtained upon request ${ }^{7}$. The ad-hoc unbalanced panel used in this paper contains selected balance sheet variables of foreign branches of US global banks located in 94 host countries over the period 1990-2015.

The empirical investigation is based on the approach proposed by Ashcraft (2006) and Gambacorta and Marquez-Ibanez (2011). The identification strategy of local credit supply by foreign branches of US banks in this paper, however, accounts for financial constraints that arise at the host country level rather than at the individual institution level, given the nature of

\footnotetext{
${ }^{6}$ Branches with total assets more than $\$ 50$ million and less than $\$ 250$ million file the FFIEC 030S report form; these are excluded from the empirical analysis presented in the paper.

${ }^{7}$ FFIEC 0030 data has been seldom analysed in the literature. Two notable exceptions are Liu and Pogach (2017) and D'Avino (2017).
} 
the data ${ }^{8}$. Following a monetary policy shock, changes in net worth of borrowers affecting credit demand, are difficult to disentangle from banks' altered capacity to supply loans. Hence, the identification of the BLC requires the detection of the type of demand-independent financial constraint whose cross-sectional variation can explain the different impact of monetary policy on loan provision by banks. Cross-sectional financial constraints faced by banks can be due to size (Kashyap and Stein, 1995), liquidity (Kashyap and Stein, 1997), leverage and capitalisation (Kishan and Opiela, 2000) and affiliation with a bank-holding company (Ashcraft, 2006). The identification strategy has to be carefully tailored to the task of the research. The aim of the empirical methodology presented in this paper is to evaluate the impact of US unconventional monetary policy on loan supply of foreign branches of US banks. If US monetary policy has an effect on the lending of these latter entities, as suspected here, then it is reasonable to assume that local loan demand is unaffected by such foreign shock. Credit quality of local borrowers is, on the other hand, clearly dependent on host-countries' monetary policy stances.

Variation in financial constraints faced by US banks by country of location may be due to different factors. A first set of factors can be traced back to the aggregate balance sheet of foreign branches by host country. Aggregate size can be a potential candidate as relative foreign importance may be associated with varying degree of access to wholesale funding. Large foreign operations, indeed, typically occur in international financial centres in which US banks play a key role and have easier access to pool of non-deposit liquidity. High reliance on liquidity raised from interbank and other wholesale markets may also explain the heterogeneous impact of US monetary shocks on loan supply of branches located abroad. Hostcountry variation in financial constraints faced by branches of US banks may also be due to local institutional and regulatory arrangements. Although foreign branches comply with Federal Reserve regulation, local restriction on banks' access to capital markets can hinder the availability of non-deposit funding at the branch level. These variations in financial constraints are formally accounted for in the empirical investigation that follows to identify local credit supply of foreign branches.

\footnotetext{
${ }^{8}$ Using aggregated balance sheet data has also the added advantage to allow for the assessment of the overall impact of the BLC on aggregate credit, in the spirit of Bernanke and Blinder (1992).
} 
The estimated econometric model has the following form:

$$
\begin{aligned}
\Delta \ln (\text { loans })_{i, t} & =\mu_{i}+\sum_{j=1}^{J} \alpha_{j} \Delta \ln (\text { loans })_{i, t-j}+\Lambda X_{i, t-1}+\Xi Z_{i, t-1}+\Pi W_{U S, t-1} \\
& +\left(\psi_{0}+\psi_{1} * Q E\right) \operatorname{Res}_{U S, t-1}+\varepsilon_{i, t}
\end{aligned}
$$

Where $i, i=1, \ldots, I$, refers to the host countries in which foreign branches of US banks are located over the sample period $t=1, \ldots, T . \mu_{i}$ captures host country specific, time invariant effects capturing local institutional and regulatory arrangements. $\Delta \ln (\text { loans })_{i, t}$ is the change in the logarithm of loans granted by foreign branches of US banks located in $i$. These include loans and leases secured by real estate, due from depository institutions and commercial and industrial claims (net of unearned income). Some specifications also consider as dependent variable the breakdown of total loans, expressed also in first-differenced logs, in loans secured by real estate, MORTG, commercial and industrial loans, COMM, and loans to depository institutions, INT.

The vector $X_{i, t-1}$ contains lagged balance sheet variables of branches by host country. These include the $\log$ of total assets, SIZE, non-deposit funding as a ratio to assets, WHOLESALE, interbank deposits as a ratio to assets, $I B K$, and interoffice liabilities as a ratio to assets. These latter are further segmented into liabilities due to branches, IO_BRA, and subsidiaries, $I O \_S U B$, and are available from 2003 onwards only.

The vector $Z_{i, t-1}$ contains lagged host country macro controls: change in interest rates, $D I R$, and real GDP growth, GDP. The vector $W_{U S, t-1}$ contains lagged US controls. These include change in fed policy rate, $U S_{-} I R_{-} G$, real GDP growth, $U S \_G D P \_G$, and the logged difference of the excess reserves held by US banks to assets, $\operatorname{ReS}_{U S}$ to account for the unconventional monetary policy carried out by the Fed. In order to empirically capture the mechanism at work as described in section 2.1, a quantitative-based measure of monetary policy proxy of this kind is particularly suitable. As showed by Apergis and Christou (2015) and Heryan and Tzeremes (2017), the ability of a policy-steered interest rate to affect bank lending is impaired when interest rates approach the zero lower bound. The interaction variable $Q E * \operatorname{Res}_{U S, t-1}$ captures the second wave of $\mathrm{QE}$ where $Q E$ is a time dummy that takes the 
value of 1 over the following periods: November 2010 - June 2011 (QE2 phase 1) and October 2012 - October 2014 (QE2 phase 2) ${ }^{9}$.

Model (1) is estimated by means of a dynamic Generalised Method of Moments (GMM), as pioneered by Arellano and Bond (1991), Arellano and Bover (1995) and Blundell and Bond (1998). In particular, it is here used the orthogonal deviation estimator developed by Arellano and Bover (1995). This methodology corrects for endogeneity by including lagged differences of the dependent variable in the instruments list ${ }^{10}$. The estimates are consistent and unbiased in the absence of autocorrelation (tested by $\operatorname{AR}(p)$ test) providing that the SarganHansen test for over-identifying restrictions supports the validity of the instruments.

In order to avoid loss of information due to the unbalanced nature of the panel constructed from the FFIEC030 survey, two different strategies are used to estimate (1) as further detailed in the next two sections.

\subsection{Quarterly dataset}

A first set of specifications is estimated using quarterly data, capturing the effect of US QE on local lending by large and medium foreign branches which compile the FFIEC030 report on a quarterly basis; these host countries can be considered as core locations. Only for a handful of host countries quarterly data is available consistently over the 1990-2015 sample; this is the case for: The Bahamas, Belgium, Cayman Island, England, Hong Kong, Japan, Puerto Rico and Singapore. For a number of host countries, foreign branches of US banks started reporting consistently on a quarterly basis from mid/late 1990s. This is the case for: Australia, India, Indonesia, South Korea, Philippines, South Africa, Taiwan and Thailand. In Canada and Germany quarterly consecutive reporting starts in early 2000s. There are a number of host countries for which data is reported mainly quarterly with little gaps, such as Argentina, Bahrain, Channel Islands, Chile, China, France, Ireland, Italy and Spain. For such host countries with limited data gaps linear interpolation is used to obtain a quarterly balanced panel. Two dummies are further used to identify international and offshore financial centres (IFC). Small financial centres, as identified by Lane and Milesi-Ferretti (2013) - The Bahamas, Bahrain, Cayman Islands and Channel Islands - are capture by IFC. The same set of countries including England is captured by $I F C_{-} E$.

\footnotetext{
${ }^{9} \mathrm{QE} 1$ is disregarded as banks retained most of the QE liquidity to make up for losses incurred in their balance sheet.

${ }^{10}$ Instruments also include lagged exogenous variables. US controls are here treated as exogenous.
} 
Time dummies are included in all specifications to account for changes in local loan demand. The final sample for the quarterly analysis comprises a total of 29 host countries, listed in Table 1 below.

\section{Table 1: Core host countries}

\begin{tabular}{|lll|}
\hline ARGENTINA & GERMANY & PUERTO RICO \\
AUSTRALIA & HONG KONG & SINGAPORE \\
BELGIUM & INDIA & SOUTH AFRICA \\
BRAZIL & INDONESIA & SPAIN \\
CANADA & IRELAND & SWITZERLAND \\
CHILE & ITALY & TAIWAN \\
CHINA & JAPAN & THAILAND \\
ENGLAND & KOREA, SOUTH \\
FRANCE & PHILIPPINES \\
& Small Offshore Financial Centres (IFC) \\
THE BAHAMAS & CAYMAN ISLANDS \\
BAHRAIN & CHANNEL ISLANDS \\
\hline
\end{tabular}

\subsection{Annual dataset}

The annual dataset includes those host countries in which US banks' branches have total assets in excess of $\$ 250$ million but less than $\$ 2 \mathrm{bn}$ which can be considered a secondary locations. A closer look at the data reveals a geographical shift in the size of foreign operations of US banks away from those locations with less substantial activities, i.e. which have mainly annual data. In 2005q4, in particular, a discontinuity of reporting is observed for a number of host countries such as Cameroon, El Salvador, Greece, Haiti, Jamaica, Lebanon, Malaysia, Peru, Senegal and Turkey. These countries are excluded from the sample as data relative to the QE implementation period is unavailable. The final dataset features variables for a total of 27 host countries, as reported in Table 2. In these host countries foreign branches have relatively higher loan portfolios and low engagement in off-balance sheet activities compared to core host countries.

Table 2: Secondary host countries

\begin{tabular}{|lll|}
\hline ABU DHABI & GUAM & PAKISTAN \\
ALGERIA & GUATEMALA & PANAMA \\
BANGLADESH & ISRAEL & PARAGUAY \\
BRITISH VIRGIN ISLANDS & JORDAN & SRI LANKA \\
BRUNEI & KENYA & TUNISIA \\
BULGARIA & MACAU & URUGUAY \\
DOMINICAN REPUBLIC & MALAYSIA & VENEZUELA \\
ECUADOR & NETHERLANDS & VIETNAM \\
EGYPT & NEW ZEALAND & VIRGIN ISLANDS OF THE U.S. \\
\hline
\end{tabular}


Table 3 reports the descriptive statistics of all the series included in the empirical analysis. On average, core host countries feature higher reliance on wholesale funding and on internal capital markets. Secondary locations, on the other hand, depict a relatively higher loan portfolio and GDP growth. The largest host countries by asset size are offshore financial centres such as Cayman Island and the Bahamas as well as England, all countries included in the quarterly panel. These are also the locations that feature relatively small loan to assets ratios.

\section{Table 3. Descriptive statistics}

\begin{tabular}{|c|c|c|c|c|c|c|}
\hline & Mean & Median & $\begin{array}{c}\text { Maximum } \\
\text { Quarterly }\end{array}$ & Minimum & Std. Dev. & Observations \\
\hline COMM & 0.005 & -0.002 & 13.547 & -11.189 & 1.131 & 2706 \\
\hline$I N T$ & -0.014 & -0.008 & 17.208 & -14.331 & 2.511 & 2152 \\
\hline$D(\ln ($ loans $))$ & 0.003 & 0.011 & 7.129 & -7.830 & 0.550 & 2814 \\
\hline$D I R$ & -0.106 & 0.000 & 59.884 & -47.897 & 2.257 & 2600 \\
\hline $\operatorname{Res} u s$ & 0.040 & 0.012 & 1.760 & -0.377 & 0.255 & 2755 \\
\hline$G D P$ & 3.446 & 3.236 & 28.143 & -17.929 & 3.676 & 2626 \\
\hline$I B K$ & 0.072 & 0.035 & 0.764 & 0.000 & 0.098 & 2853 \\
\hline$I O \_B R A$ & 0.397 & 0.336 & 0.995 & 0.001 & 0.252 & 1421 \\
\hline$I O \_S U B$ & 0.092 & 0.035 & 0.938 & 0.000 & 0.130 & 1421 \\
\hline$M O R T G$ & -0.020 & -0.003 & 19.750 & -10.454 & 1.127 & 1988 \\
\hline SIZE & 16.017 & 15.741 & 21.146 & 9.335 & 1.644 & 2853 \\
\hline$U S \_G D P \_G$ & 2.443 & 2.700 & 5.300 & -4.100 & 1.808 & 2929 \\
\hline$U S \_I R \_G$ & -0.072 & -0.005 & 0.727 & -1.433 & 0.429 & 2900 \\
\hline WHOLESALE & 0.575 & 0.562 & 1.000 & 0.001 & 0.249 & 2853 \\
\hline & & & Annual & & & \\
\hline COMM & -0.019 & -0.018 & 12.952 & -7.865 & 1.070 & 604 \\
\hline$I N T$ & -0.319 & -0.252 & 8.705 & -9.560 & 2.894 & 166 \\
\hline$D(\ln ($ loans $))$ & 0.041 & 0.032 & 6.825 & -6.042 & 0.675 & 660 \\
\hline$D I R$ & -0.613 & 0.000 & 91.538 & -119.281 & 8.201 & 514 \\
\hline Resus & 0.040 & 0.004 & 0.866 & -0.064 & 0.178 & 648 \\
\hline$G D P$ & 4.371 & 4.419 & 26.755 & -20.349 & 3.735 & 624 \\
\hline$I B K$ & 0.047 & 0.007 & 0.992 & 0.000 & 0.093 & 701 \\
\hline$I O \_B R A$ & 0.208 & 0.177 & 0.909 & 0.000 & 0.144 & 350 \\
\hline$I O \_S U B$ & 0.022 & 0.002 & 0.397 & 0.000 & 0.060 & 349 \\
\hline MORTG & -0.054 & -0.020 & 20.307 & -11.165 & 1.729 & 287 \\
\hline SIZE & 13.000 & 13.118 & 15.793 & 4.078 & 1.267 & 702 \\
\hline$U S \_G D P \_G$ & 2.389 & 2.638 & 4.675 & -2.775 & 1.679 & 702 \\
\hline$U S \_I R \_G$ & -0.072 & -0.012 & 0.544 & -1.085 & 0.379 & 675 \\
\hline WHOLESALE & 0.340 & 0.297 & 1.000 & 0.002 & 0.204 & 702 \\
\hline
\end{tabular}

Source: Author's computation based on FFIEC 030 data. 


\section{Results}

\subsection{Core host countries}

Table 4 reports the estimates of three specification of model (1) which differ with regards to liability-side variables considered and where $\operatorname{DEPNT}(p)$ refers to the lags of the dependent variable, $\Delta \ln (\text { loans })_{i, t}$ in this case. Wholesale/non-deposit funding is accounted for in the left-hand side panel (baseline regression) while the middle and the right-hand side panels report the regression estimates with the breakdown of non-deposit debt raised by foreign branches from interbank and internal capital markets.

The estimated coefficients of the lagged dependent variable are significant and negative, implying that there is a tendency of the growth rate of loans to converge to a longrun trend. The response of bank lending to local macroeconomic factors have the expected signs across specifications and are overall significant with local loan supply of foreign branches of US bank reacting negatively to local interest rates and positively to GDP growth. The effect of local interest rate on branches' lending is not significant in the specification in the righthand side panel which is estimated on a smaller time sample due to data availability (starting from end-2003) suggesting that the link between local monetary policy and lending has broken down in the last decade or so. The estimated coefficient of $U S_{-} I R_{-} G$ is positive and significant in the first two panels for the 1990-2015 sample period. Lending of foreign branches of US banks increases in the range of 3.6-4\% following a $1 \%$ increase in the Fed rate. This evidence suggests that global banks compensate a tightening in monetary policy-induced credit conditions in the US with an increase in their foreign lending. This result is in line with the arguments advanced by Goetz et al., (2013) and Markowitz (1952) who state that geographical diversification can allow banks to enhance their revenues and better shed from idiosyncratic, i.e. country-specific, shocks. The negative coefficient of SIZE can be explained by the fact that the activities of foreign branches are larger in IFC where they have substantial interoffice and interbank positions and little loans.

The interaction variable is positive and significant across specifications suggesting an amplified effect of US monetary policy on lending of foreign branches of US banks during the QE. The estimated coefficients of interoffice liabilities of foreign branches during the QE period, as shown in the specification in the right-hand-side panel, are positive and strongly significant for both liabilities due to related branches and subsidiaries' variables. This implies an intensification of internal borrowings of foreign branches of US banks during the QE implementation period in the US. Overall, these result suggests that global banks have 
undergone significant liquidity reallocations via internal capital markets during the QE period in the US and that the increase in QE-created liquidity was distributed across the banking network to extend foreign lending.

Table 4. GMM regression estimates, dependent variable: $\Delta \ln (\text { loans })_{i, t}$

\begin{tabular}{|c|c|c|c|c|c|c|}
\hline \multirow[b]{2}{*}{ Variable } & \multicolumn{2}{|c|}{ Baseline regression } & \multicolumn{2}{|c|}{ Interbank liabilities } & \multicolumn{2}{|c|}{ Internal capital markets } \\
\hline & Coefficient & Std. Error & Coefficient & Std. Error & Coefficient & Std. Error \\
\hline DEPNT(-1) & $-0.309 * * *$ & 0.020 & $-0.355^{* * *}$ & 0.008 & $-0.358 * * *$ & 0.020 \\
\hline DEPNT(-2) & $-0.072 * * *$ & 0.017 & $-0.092 * * *$ & 0.005 & $-0.087 * * *$ & 0.019 \\
\hline GDP(-1) & $0.012 * * *$ & 0.003 & $0.007 * * *$ & 0.001 & $0.008 * * *$ & 0.002 \\
\hline $\operatorname{SIZE}(-1)$ & $-0.059 * * *$ & 0.016 & $-0.066 * * *$ & 0.004 & $-0.060 * * *$ & 0.021 \\
\hline $\operatorname{DIR}(-1)$ & $-0.005 * * *$ & 0.002 & $-0.007 * * *$ & 0.001 & -0.005 & 0.008 \\
\hline US_GDP_G(-1) & 0.208 & 0.205 & 0.099 & 0.125 & 0.615 & 0.681 \\
\hline US_IR_G(-1) & $3.610 * * *$ & 0.114 & $4.027 * * *$ & 0.582 & 0.163 & 16.968 \\
\hline QE & 0.267 & 0.694 & -0.254 & 0.289 & -0.014 & 1.217 \\
\hline RESus(-1) & 0.079 & 0.575 & -0.670 & 1.175 & $-8.894 *$ & 4.871 \\
\hline $\operatorname{RESus}(-1) * \mathrm{QE}$ & $3.052 * *$ & 1.531 & $3.537 * *$ & 1.807 & $12.478 * * *$ & 4.837 \\
\hline WHOLESALE(-1) & $0.203 * * *$ & 0.063 & $0.141 * * *$ & 0.021 & 0.106 & 0.156 \\
\hline WHOLESALE(-1)*QE & -0.037 & 0.054 & -0.009 & 0.024 & $-0.688 * * *$ & 0.185 \\
\hline IO_BRA(-1) & & & & & 0.263 & 0.169 \\
\hline IO_SUB(-1) & & & & & $0.419 * *$ & 0.186 \\
\hline IO_BRA(-1)*QE & & & & & $0.653 * * *$ & 0.152 \\
\hline IO_SUB $(-1) * \mathrm{QE}$ & & & & & $1.131 * * *$ & 0.171 \\
\hline $\operatorname{IBK}(-1)$ & & & $0.070^{*}$ & 0.039 & & \\
\hline $\operatorname{IBK}(-1) * \mathrm{QE}$ & & & $-0.287 * *$ & 0.128 & & \\
\hline Sample & \multicolumn{2}{|c|}{$1990 q 4-2015 q 4$} & \multicolumn{2}{|c|}{$1990 q 4-2015 q 4$} & \multicolumn{2}{|c|}{$2003 q 4-2015 q 4$} \\
\hline Observations & \multicolumn{2}{|c|}{2059} & \multicolumn{2}{|c|}{2059} & \multicolumn{2}{|c|}{1075} \\
\hline Sargan-Hansen, p-value & \multicolumn{2}{|c|}{0.178} & \multicolumn{2}{|c|}{0.732} & \multicolumn{2}{|c|}{0.489} \\
\hline $\mathrm{AR}(2)$ & \multicolumn{2}{|c|}{0.422} & \multicolumn{2}{|c|}{0.336} & \multicolumn{2}{|c|}{0.607} \\
\hline Host-countries & \multicolumn{2}{|c|}{23} & \multicolumn{2}{|c|}{23} & \multicolumn{2}{|c|}{23} \\
\hline
\end{tabular}

Table 5 reports the estimates of the baseline regression in which local loans (dependent variable) are broken down by loan type: secured by real estate, commercial and industrial and to depository institutions. The amplification effect of the excess reserves held by US banks on local loans secured by real estate (left-hand side panel) during the QE period is strongly significant. In particular, a $1 \%$ increase in excess reserves on the balance sheet of US banks located in the US on loans secured by real estate is on average $1.8 \%$ higher during the second and third waves of QE than otherwise. Also, the estimated coefficient of RESUS(-1)* $Q E$ in the middle panel suggests that a $1 \%$ increase in excess reserves on foreign commercial and industrial loans is $12 \%$ higher during the QE2 period than otherwise, albeit this estimate is 
significant only at $10 \%$ confidence level. The estimated coefficient of RESUS(-1)*QE in the right-hand side panel of Table 5 reveals that the QE in the US had no incremental significant effect on interbank lending by foreign offices of US banks.

Table 5. GMM regression estimates, local loans breakdown

\begin{tabular}{|c|c|c|c|c|c|c|}
\hline \multirow{2}{*}{$\begin{array}{l}\text { Dependent Variable: } \\
\text { Variable }\end{array}$} & \multicolumn{2}{|c|}{ MORTG } & \multicolumn{2}{|c|}{ COMM } & \multicolumn{2}{|c|}{$I N T$} \\
\hline & Coefficient & Std. Error & Coefficient & Std. Error & Coefficient & Std. Error \\
\hline DEPNT(-1) & $-0.835 * * *$ & 0.007 & $-0.893 * * *$ & 0.027 & $-0.935^{* * *}$ & 0.048 \\
\hline DEPNT(-2) & $-0.307 * * *$ & 0.007 & $-0.454 * * *$ & 0.018 & $-0.377 * * *$ & 0.046 \\
\hline GDP(-1) & -0.000 & 0.001 & $-0.019 *$ & 0.010 & -0.004 & 0.036 \\
\hline $\operatorname{SIZE}(-1)$ & $-0.120 * * *$ & 0.011 & $-0.178 * * *$ & 0.062 & -0.200 & 0.131 \\
\hline $\operatorname{DIR}(-1)$ & $-0.015^{* * *}$ & 0.004 & 0.034 & 0.026 & -0.016 & 0.034 \\
\hline US_GDP_G(-1) & $-0.305 * * *$ & 0.019 & 0.261 & 0.373 & -0.290 & 0.232 \\
\hline US_IR_G(-1) & $1.416^{* * *}$ & 0.101 & 0.357 & 1.589 & $1.489 * *$ & 0.747 \\
\hline WHOLESALE(-1) & $0.242 * * *$ & 0.051 & 0.200 & 0.251 & 0.428 & 0.643 \\
\hline WHOLESALE $(-1) * \mathrm{QE}$ & -0.059 & 0.064 & -0.314 & 0.349 & 0.530 & 0.348 \\
\hline QE & 0.059 & 0.061 & -1.244 & 0.756 & 6.610 & 4.916 \\
\hline RESus(-1) & -0.135 & 0.086 & 1.993 & 5.022 & 0.668 & 1.189 \\
\hline RESus(-1)*QE & $1.786^{* * *}$ & 0.630 & $12.291 *$ & 6.690 & -89.464 & 68.237 \\
\hline Sample & \multicolumn{2}{|c|}{$1990 q 4-2015 q 4$} & \multicolumn{2}{|c|}{ 1990q4-2015q4 } & \multicolumn{2}{|c|}{$1990 \mathrm{q} 4-2015 \mathrm{q} 4$} \\
\hline Observations & \multicolumn{2}{|c|}{1379} & \multicolumn{2}{|c|}{1980} & \multicolumn{2}{|c|}{1526} \\
\hline Sargan-Hansen, p-value & \multicolumn{2}{|c|}{0.930} & \multicolumn{2}{|c|}{0.708} & \multicolumn{2}{|c|}{0.100} \\
\hline $\operatorname{AR}(2)$ & \multicolumn{2}{|c|}{0.449} & \multicolumn{2}{|c|}{0.343} & \multicolumn{2}{|c|}{0.090} \\
\hline Host-countries & \multicolumn{2}{|c|}{22} & \multicolumn{2}{|c|}{23} & \multicolumn{2}{|c|}{23} \\
\hline
\end{tabular}

Table 6 below explores this result further by focusing on international financial centres as, in contrast to other locations, IFC have large interbank positions which may have been affected by the QE in the US ${ }^{11}$. The two specifications consider the subgroups $I F C$ and IFC_E in the left-hand and right-hand side panels respectively. The estimated coefficient of the QE dummy is significant and positive in both specifications, implying that interbank lending increased by $1.4 \%$ and $1.3 \%$ in the $I F C$ and $I F C \_E$ groups respectively during the QE period. The interaction variable RESUS(-1)* $Q E$ is positive and strongly significant in the IFC group regression suggesting that during the QE in the US the impact on interbank lending of international financial centres was about $11 \%$ higher than during non-QE periods. This incremental effect is still large and equal to about $12 \%$ but significant only at $10 \%$ confidence

\footnotetext{
${ }^{11}$ In these specifications wholesale funding is excluded from the set of controls due to its high correlation with SIZE. This is due to the fact that branches located in IFC have a negligible deposit base and most assets are financed with wholesale raised funding.
} 
level when England is added to the IFC group. This evidence suggests that IFC, which are already greatly engaged in intermediating global liquidity in normal times, have increased even further their activities in interbank markets during the QE period.

Table 6. GMM regression estimates, focus on IFC, dependent variable: $I N T_{i, t}$

\begin{tabular}{|c|c|c|c|c|}
\hline Dependent variable: & \multicolumn{4}{|c|}{ INT } \\
\hline Sample: & \multicolumn{2}{|c|}{ IFC } & \multicolumn{2}{|c|}{ IFC_E (including England) } \\
\hline Variable & Coefficient & Std. Error & Coefficient & Std. Error \\
\hline DEPNT(-1) & $-0.960 * * *$ & 0.004 & $-0.965 * * *$ & 0.012 \\
\hline DEPNT(-2) & $-0.844 * * *$ & 0.007 & $-0.837 * * *$ & 0.023 \\
\hline DEPNT(-3) & $-0.732 * * *$ & 0.008 & $-0.752 * * *$ & 0.014 \\
\hline GDP(-1) & -0.004 & 0.009 & -0.012 & 0.007 \\
\hline $\operatorname{SIZE}(-1)$ & $-0.173 * * *$ & 0.042 & $-0.164 * * *$ & 0.038 \\
\hline $\operatorname{DIR}(-1)$ & $-0.139 * * *$ & 0.027 & -0.020 & 0.042 \\
\hline US_GDP_G(-1) & $-0.663 * *$ & 0.336 & $-0.892 *$ & 0.470 \\
\hline US_IR_G(-1) & $-12.704 * * *$ & 1.880 & $-12.360 * * *$ & 3.665 \\
\hline $\mathrm{QE}$ & $1.421 * * *$ & 0.211 & $1.312 * * *$ & 0.455 \\
\hline RESus(-1) & $-24.194 * * *$ & 1.932 & $-25.233 * * *$ & 6.856 \\
\hline RESus(-1)*QE & $11.241 * * *$ & 2.893 & $12.464 *$ & 6.696 \\
\hline Sample & \multicolumn{2}{|c|}{$1990 q 4-2015 q 4$} & \multicolumn{2}{|c|}{$1990 q 4-2015 q 4$} \\
\hline Observations & \multicolumn{2}{|c|}{362} & \multicolumn{2}{|c|}{455} \\
\hline Sargan-Hansen, p-value & \multicolumn{2}{|c|}{0.423} & \multicolumn{2}{|c|}{0.145} \\
\hline $\operatorname{AR}(2)$ & \multicolumn{2}{|c|}{0.873} & \multicolumn{2}{|c|}{0.868} \\
\hline Host-countries & \multicolumn{2}{|c|}{4} & \multicolumn{2}{|c|}{5} \\
\hline
\end{tabular}

Notes: The table reports the estimates of generalized method of moments panel regression using an orthogonal deviation estimator (system estimator). $D E P N T(p)$ variable refers to lagged dependent variable. AR(2) tests are obtained from the GMM differenced estimators. Robust standard errors in parenthesis. $* * *, * *, *$ refer to $1 \%, 5 \%$ and $10 \%$ significance levels, respectively.

\subsection{Secondary host countries: Annual data}

Table 7 below reports the estimated of (1) considering the secondary host countries sample. The dependent variable in left-hand side specification is $\Delta \ln (\operatorname{loans})_{\mathrm{i}, \mathrm{t}}$ while in the other specifications the components of local loans are considered separately. Overall, the estimates of the control variables are in line with what observed in the regressions for the core locations. However, the effect of the US QE on local loans is somewhat different. Total local loans extended by foreign branches of banks located in secondary locations have increased significantly during the QE period with the coefficient of the dummy QE being equal to 0.135 in the left-hand side panel. This is due to an increase in commercial and industrial loans (third panel). The last specification of Table 7 reveals a significant augmentation of the effect of QE programme on local interbank loans: a 1\% increase in excess reserves of US domesticallylocated banks amplified the effect of local lending of foreign branches of US banks to other banks by about $4.5 \%$ during the QE period at a $5 \%$ confidence level. 
The diagnostic tests reported at the bottom of each specification considered in the empirical analysis reveal the absence of autocorrelation and the validity of the instruments, necessary for the unbiasedness and consistency of the estimators.

Table 7. GMM regression estimates, local loans breakdown

\begin{tabular}{|c|c|c|c|c|c|c|c|c|}
\hline Dependent variable: & \multicolumn{2}{|c|}{ All loans } & \multicolumn{2}{|c|}{ MORTG } & \multicolumn{2}{|c|}{ COMM } & \multicolumn{2}{|c|}{$I N T$} \\
\hline Variable & Coefficient & $\begin{array}{c}\text { Std. } \\
\text { Error }\end{array}$ & Coefficient & $\begin{array}{c}\text { Std. } \\
\text { Error }\end{array}$ & Coefficient & $\begin{array}{c}\text { Std. } \\
\text { Error }\end{array}$ & Coefficient & $\begin{array}{l}\text { Std. } \\
\text { Error }\end{array}$ \\
\hline DEPNT(-1) & 0.022 & 0.044 & $-0.617 * * *$ & 0.117 & $-1.013 * * *$ & 0.211 & $-0.762 * * *$ & 0.042 \\
\hline DEPNT(-2) & $-0.145 * *$ & 0.061 & -0.286 & 0.211 & $-0.693 * * *$ & 0.215 & $-0.430 * * *$ & 0.038 \\
\hline GDP(-1) & $0.028 * * *$ & 0.006 & $0.269^{* *}$ & 0.119 & 0.021 & 0.029 & $0.083^{* * *}$ & 0.013 \\
\hline $\operatorname{SIZE}(-1)$ & $-0.200 * * *$ & 0.036 & -0.156 & 2.359 & -0.1667 & 0.185 & $-1.084 * * *$ & 0.147 \\
\hline $\operatorname{DIR}(-1)$ & $-0.013 * * *$ & 0.004 & $-0.174 * *$ & 0.067 & -0.042 & 0.037 & $-0.010 * * *$ & 0.002 \\
\hline US_GDP_G(-1) & 0.009 & 0.012 & -0.328 & 0.251 & $0.165^{* *}$ & 0.072 & 0.298 & 0.051 \\
\hline US_IR_G(-1) & $0.095^{*}$ & 0.049 & $1.339^{*}$ & 0.680 & -0.020 & 0.170 & $-0.878 * * *$ & 0.126 \\
\hline WHOLESALE(-1) & $-0.379 * *$ & 0.190 & $3.399 *$ & 2.042 & -0.254 & 0.632 & $5.260 * * *$ & 0.583 \\
\hline QE & $0.135 * * *$ & 0.045 & -1.188 & 1.734 & $0.976^{* * *}$ & 0.368 & -0.479 & 0.409 \\
\hline RESus(-1) & $0.165^{* * *}$ & 0.059 & $2.408^{* * *}$ & 0.865 & 0.016 & 0.178 & -0.240 & 0.401 \\
\hline RESus(-1)*QE & -0.391 & 0.398 & -1.675 & 3.602 & -1.146 & 1.130 & $4.461 * *$ & 1.973 \\
\hline Sample & \multicolumn{2}{|c|}{$1990-2015$} & \multicolumn{2}{|c|}{$1990-2015$} & \multicolumn{2}{|c|}{$2003 q 4-2015 q 4$} & \multicolumn{2}{|c|}{$1990-2015$} \\
\hline Observations & \multicolumn{2}{|c|}{433} & \multicolumn{2}{|c|}{122} & \multicolumn{2}{|c|}{383} & \multicolumn{2}{|c|}{78} \\
\hline Sargan-H., p-value & \multicolumn{2}{|c|}{0.823} & \multicolumn{2}{|c|}{0.941} & \multicolumn{2}{|c|}{0.890} & \multicolumn{2}{|c|}{0.630} \\
\hline $\operatorname{AR}(2)$ & \multicolumn{2}{|c|}{0.715} & \multicolumn{2}{|c|}{0.898} & \multicolumn{2}{|c|}{0.675} & \multicolumn{2}{|c|}{0.129} \\
\hline Host-countries & \multicolumn{2}{|c|}{21} & \multicolumn{2}{|c|}{15} & \multicolumn{2}{|c|}{21} & \multicolumn{2}{|c|}{12} \\
\hline
\end{tabular}

Notes: The table reports the estimates of generalized method of moments panel regression using an orthogonal deviation estimator (system estimator). $D E P N T(p)$ variable refers to lagged dependent variable. AR(2) tests are obtained from the GMM differenced estimators. Robust standard errors in parenthesis. $* * *, * *, *$ refer to $1 \%, 5 \%$ and $10 \%$ significance levels, respectively.

\section{Robustness checks}

We consider several robustness checks in order to validate the key results presented in section 4. Most notably, we re-estimate model (1) by accounting for: (1) geographical areas, (2) unconventional monetary policy in other countries and (3) the three QE periods separately.

Table A.1 in the appendix reports the regression estimates of (1) for regional subgroups of host countries, in which the dependent variable is the total amount of lending of foreign branches of US global banks. The specification reported in panel (a) considers core host countries located in Asia and South America available in the quarterly dataset while in panel (b) are reported the regression estimates for the subsample of all other core host countries. In panels (c) and (d), instead, (1) is estimated for the Asian and South American and other secondary host countries respectively (annual panel). Branches located in the core countries in the Asian and South American region have depicted the largest increase in loans in response to the US QE, as shown by the estimated coefficient of $\operatorname{RESUS}(-1)^{*} Q E$ which is strongly significant and equal to 13.984. In other core locations, comprising mainly European host 
countries, on the other hand, there was a significant retrenchment, i.e. at 5\% significance level, in local lending by US banks via their branches following the US QE policy. In secondary locations, on the other hand, the US QE programme has not had any significant effect on local lending, albeit results suggest an increase in lending during the US QE period, as depicted by the estimated coefficients of $Q E$ in columns (c) and (d). Consistent with the previous results, there is no significant increase in local lending due to the US QE even when regional disaggregation is considered as the estimated coefficient of RESUS(-1)* $Q E$ are not significant in both specifications in (c) and (d).

The estimates of the specifications accounting for unconventional monetary policy in the Euro area, UK and Japan are reported in Table A.2. This is to control for the possibility that a surge in post-crisis global liquidity created by central banks worldwide may have further eased the pressure in international lending markets (Avdjiev et al., 2017). Non-US post-2007 quantitative easing measures are proxied by base money (M0) indices for the UK, $M 0 \_U K$, the Euro area, $M 0 \_E A$, and Japan, $M 0 \_J P^{12}$. In particular, we replicate the previously identified channels of transmission of QE activated by US global banks: that is, via real estate and commercial loans in core locations and interbank loans in secondary locations. The estimated coefficient of RESUS(-1)* $Q E$ are robust across specifications (a), (b) and (c) with significant and positive estimates, confirming previous findings. Liquidity created by QE programmes in the UK and Japan is found to have significantly increased outstanding mortgages by foreign branches of US banks in core locations, while the QE programme by the European Central Bank has had a positive effect on interbank loans issued in secondary locations.

An additional battery of robustness checks considers the three different QE waves separately. The empirical analysis presented above focuses on the last two waves of the QE programme implemented by the Fed, occurring over the two following periods: from November 2010 until June 2011 (QE2 - phase 1), from October 2012 until October 2014 (QE2 - phase 2). Given the emphasis of this paper to uncover the effect of QE on foreign lending, the first wave of QE by the Fed was disregarded under the presumption that during that period banks retained most of the QE liquidity to make up for losses incurred in their balance sheet and to support domestic lending (see Gertler, 2013, for a discussion). Still, different waves of QE might have had heterogeneous impact on international bank lending of US banks. Focusing on domestic lending, Rodnyansky and Darmouni (2017), for instance, show that the third wave

\footnotetext{
12 The M0 variables are considered in first differences of the logs; the base of the index is 20001q1. Sources are Bank of England (UK M0), European Central Bank (Euro area M0) and Bank of Japan (Japan M0).
} 
of the QE policy by the Federal reserves (i.e. QE2, phase 2) had the largest effect on domestic lending, while the second phase (i.e. QE2, phase 1) had no significant effect. In table A.3 in the appendix are reported the regression estimates of (1) in which the three waves of QE are considered separately by the dummies $Q E 1, Q E 2 \_1$ and $Q E 2 \_2$ respectively. Specifications (a)-(c) and (d)-(f) consider the core and secondary locations respectively. In the core host locations in the first two waves of QE there has been a significant decrease in lending by foreign branches as the coefficients of $Q E 1$ and $Q E 2 \_1$ are negative and significant at 5\% confidence level. This result is in line with findings by the International Monetary Fund (2015) reporting a retrenchment on global banking in the years following the 2007-09 financial crisis. The QE implementation in the US has had a positive and significant effect on lending by foreign branches of US banks during the last wave of the programme, that is, during the two years period spanning from October 2012 to October 2014. Our results thus suggest that the last wave of QE programme in the US, which involved a monthly $\$ 40$ billion purchase of mortgagebased securities, boosted foreign lending of US banks in their core locations other than their domestic lending as found by Rodnyansky and Darmouni (2017). The coefficient of RESUS(1) * $Q E 2 \_2$ in column (c) is indeed strongly significant and equal to 8.441. Regression estimates for the secondary locations sample in columns (d)-(f) confirm the previous findings of no significant impact of any of the three waves of the US QE on lending by foreign branches of US global banks. There is indeed evidence of a significant decrease of overall lending of these latter in secondary locations during the last wave of the US QE programme. When considering interbank loans of foreign branches of secondary locations as dependent variable (Table A.4 in the Appendix), a similar pattern arise: only during the third wave of the QE programme by the Fed had the effect on foreign interbank lending in secondary locations is amplified significantly. The coefficient of RESUS(-1)*QE2_2 in column (c) indeed is positive and becomes strongly significant, i.e. at 1\% significance level, only when the second phase of QE2 is considered.

\section{Conclusions}

The effects of the unconventional monetary policy measures following the 2007-09 financial crisis are still to be fully appraised. While much of the academic attention has been devoted to understanding the impact of liquidity created by the QE programmes on domestic and foreign financial markets, the eventual impact on bank lending remains largely unexplored. 
This paper has attempted to provide empirical support to the existence of an international bank lending channel activated during the QE implementation by US global banks. The novel dataset used in this paper contains aggregated balance sheet variables of foreign branches of US banks by host country and is perfectly suited for this intent.

Results point to asymmetric impact of US QE on the lending of foreign branches in host-countries. In particular, in those host-countries where these entities have larger activities, i.e. core locations, a BLC was activated during the US QE implementation, resulting in an increase in branches' loans secured by real estate and commercial loans. In international and offshore financial centres, on the other hand, foreign branches of US banks have significantly increased their interbank loans during the QE period. In a similar fashion, in those hostcountries where these entities have smaller activities, i.e. secondary locations, an international BLC is activated exclusively via interbank lending.

Our findings highlight the importance of global banks in transmitting liquidity shocks across borders potentially impairing the objectives of both domestic and foreign monetary policies. As the 2007-09 global financial crisis has revealed, unsustainable debt levels foster financial instabilities and self-fulfilling feedback loops between the banking sector and the real economy. Although regulators' ability to regulated foreign banks operating in their country is rather limited, especially in the case of branches, ad-hoc macroprudential tools to limit domestic credit may contain eventual pressure on local credit markets due to QE-generated liquidity inflows via foreign banks. 


\section{References}

Ahmed, S. Zlate, A., 2014. Capital flows to emerging market economies: a brave new world?. J. Int. Money Finance 48, 221-248.

Apergis, N., Christou, C., 2015. The behaviour of the bank lending channel when interest rates approach the zero lower bound: Evidence from quantile regressions. Econ. Modelling 49, 269-307.

Arellano, M., Bond, S., 1991. Some tests of specification for panel data: Monte Carlo evidence and an application to employment equations. Rev. Econ. Stud. 58(2), 277-97.

Arellano, M., Bover, O., 1995. Another look at the instrumental-variable estimation of errorcomponents models. J. Econometrics 68, 29-52.

Ashcraft, A., 2006. New evidence on the lending channel. J. Money, Credit, Banking 38(3), 751-76.

Avdjiev, S., Gambacorta, L., Goldberg, L.S., Schiaffi, S., 2017. The shifting drivers of global liquidity. Bank for International Settlements Working Papers, No. 644.

Barroso, J.B.R., da Silva, L.A.P., Sales, A.S., 2015. QE and related capital flows into Brazil: Measuring its effects and transmission channels through a rigorous counterfactual evaluation. J. Int. Money Finance 48, 68-100.

Bernanke, B.S., 2007. The financial accelerator and the credit channel. The credit channel of monetary policy in the twenty-first century conference, June 14-15. Federal Reserve Bank of Atlanta.

Bernanke, B.S., Blinder, A.S., 1988. Credit, money, and aggregate demand. Amer. Econ. Rev.78, 435-439.

Bernanke, B.S., Blinder, A.S., 1992. The Federal Funds Rate and the Channels of Monetary Transmission. Amer. Econ. Rev. 82(4), 901-921.

Bernanke, B.S., Gertler, M., 1995. Inside the black box the credit channel of monetary policy transmission. J. Econ. Perspect. 9(27), 48.

Bernanke, B., Reinhart, V., 2004. Conducting monetary policy at very low short-term interest rates. Amer. Econ. Rev. 94(2), 85-90.

Blinder, A., 2010. Quantitative easing: entrance and exit strategies. Federal Reserve Bank of St. Louis Review, 92(6), 465-479.

Blundell, R., Bond, S., 1998. Initial Conditions and Moment Restrictions in Dynamic Panel Data Models. J. Econometrics 87(2), 115-43.

Bowman, D., Cai, F., Davies S., Kamin S., 2011. Quantitative easing and bank lending: evidence from Japan. Board of Governors of the Federal Reserve System, International Finance Discussion Papers No. 1018. 
Brana, S., Prat, S., 2016. The effects of global excess liquidity on emerging stock market returns: Evidence from a panel threshold model. Econ. Modelling 52, 26-34.

Brunner, K., Meltzer, A.H., 1973. Mr Hicks and the monetarists. Economica 40(157), 44-59.

Butt, N., Churm, R., McMahon, M., Morotz, A. ,Schanz, J., 2014. QE and the bank lending channel in the United Kingdom. Bank of England Working Paper, No. 511.

Cetorelli, N., Goldberg, L., 2012. Banking globalization and monetary transmission. J. Finance 67(5), 1811-1843.

Chen, H., Curdia, V., Ferrero, A., 2012. The macroeconomic effects of large-scale asset purchase programmes. Econ. J. 122(564), 289-315.

D'Avino, C., 2017. Banking regulation and the changing geography of off-balance sheet activities. Econ. Letters 157, 155-158.

Disyatat, P., 2010. The bank lending channel revisited. Bank for International Settlements Working Papers, No. 297.

Ehrmann, M., Gambacorta, L., Martinez-Pages, J., Sevestre, P., Worms, A., 2003. Financial systems and the role of banks in monetary policy transmission in the euro area, in Angeloni, I., Kashyap, A., Mojon, B. (Eds.), Monetary Policy Transmission in the Euro Area: A Study by the Eurosystem Monetary Transmission Network. Cambridge University Press, pp. 235-269.

Forbes, K., Reinhart D., Weiladek, T., 2017. Banking de-globalisation: a consequence of monetary and regulatory policies?. BIS Papers No. 86.

Fratzscher, M., Lo Duca, M., Straub, R. 2012. A global monetary tsunami? On the spillovers of US quantitative easing. CEPR Discussion Paper, No. 9195.

Fratzscher, M., Lo Duca, M., Straub, R., 2016. On the international spillovers of US Quantitative Easing. Econ. J. doi:10.1111/ecoj.12435.

Gagnon, J., Raskin, M., Remache, J., Sack, B., 2011. The financial market effects of the Federal Reserve's large-scale asset purchases. International Journal of Central Banking, 7(1), 3-43.

Gambacorta, L., Marques-Ibanez, D., 2011. The bank lending channel: lessons from the crisis. Econ. Pol. 26 (66), 135-82.

Garcia-Posada, M., Marchetti, M., 2016. The bank lending channel of unconventional monetary policy: The impact of the VLTROs on credit supply in Spain. Econ. Modelling 58, 427-441.

Gertler, M., 2013. Monetary Policy after August 2007. J. Econ. Educ.44 (4), 329-338.

Goetz, M. R., Laeven L., Levine R., 2013. Identifying the Valuation Effects and Agency Costs of Corporate Diversification: Evidence from the Geographic Diversification of U.S. Banks, Rev. Finan. Stud. 26(7), 1787- 1823. 
Heryan, T., Tzeremes, P.G., 2017. The bank lending channel of monetary policy in EU countries during the global financial crisis. Econ. Modelling 67, 10-22.

International Monetary Fund, 2015. International Banking After the Crisis: Increasingly Local and Safer?. Global Financial Stability Report, April, Washington International Monetary Fund.

Joyce, M., Lasaosa, A., Stevens, I., Tong, M., 2011. The financial market impact of quantitative easing. International Journal of Central Banking 7(3), 113-61.

Joyce, M., Spaltro, M., 2014. Quantitative easing and bank lending: A panel data approach. Bank of England Working Paper No. 504.

Kashyap, A.K., Stein, J.C., 1995. The impact of monetary policy on bank balance sheet. Carnegie-Rochester Conference Series on Public Policy 42, 151195.

Kashyap, A.K., Stein, J.C., 1997. The role of banks in monetary policy: A survey with implications for the European monetary union. Federal Reserve Bank of Chicago Economics Perspectives, 21(5), 2-18.

Kishan, R.P., Opiela, T.P., 2000. Bank size, bank capital, and the bank lending channel. J. Money, Credit, Banking 32(1), 121-41.

Krishnamurthy, A., and Vissing-Jorgensen, A., 2011. The effects of quantitative easing on interest rates. Unpublished manuscript, Kellogg School of Management.

Lane, P.R., Milesi-Ferretti, G.M., 2011. Cross-border investment in small international financial centers. Int. Finance 14(2), 301-30.

Liu, E., Pogach, J., 2017. The effect of foreign lending on domestic loans: an analysis of U.S global banks. International Finance Discussion Papers, Board of Governors of the Federal Reserve System, Number 1198.

Mallick, S., Mohanty, M.S., Zampolli, F., 2017. Market volatility, monetary policy and the term premium. BIS Working Papers No. 606. http://www.bis.org/publ/work606.pdf

Markowitz, H., 1952. Portfolio selection. J. Finance 7(1), 77-91.

Morais, B., Peydro, J.-L., Ruiz, C., 2015. The international bank lending channel of monetary policy rates and QE: Credit supply, reach-for-yield, and real effects. World Bank, Washington DC, Working Paper 7216.

Rodnyansky, A., Darmouni, O., 2017. The effects of quantitative easing on bank lending behaviour. Rev. Finan. Stud. 11, 3858-3887.

Stein, J., 1998. An adverse-selection model of bank asset and liability management with implications for the transmission of monetary policy. RAND J. Econ. 29(3), 466-486. 
Tobin, J., 1969. A general equilibrium approach to monetary theory. J. Money, Credit, Banking $1(1), 15-29$. 


\section{Appendix}

Fig. 1.a: Long-term deposit and loans of US commercial banks, \$bn

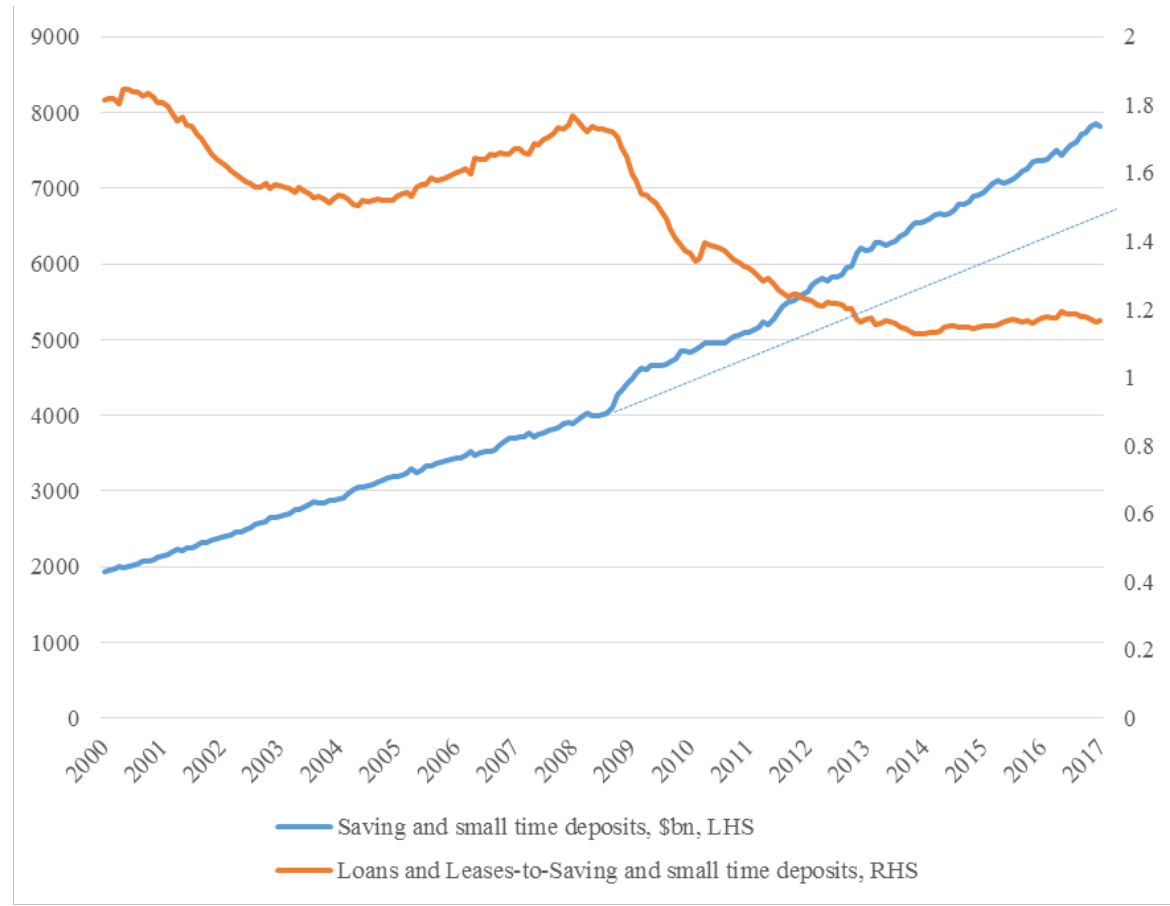

Source: Federal Reserve Bank of St. Louis.

Notes: The series reported in Figure 1.a refer to saving and small time deposits and loans and leases of US commercial banks. These include: domestically chartered commercial banks; U.S. branches and agencies of foreign banks; and Edge Act and agreement corporations (foreignrelated institutions). Data exclude International Banking Facilities.

Fig. 2.a: Domestic lending rates by country, 2014, annual percentage

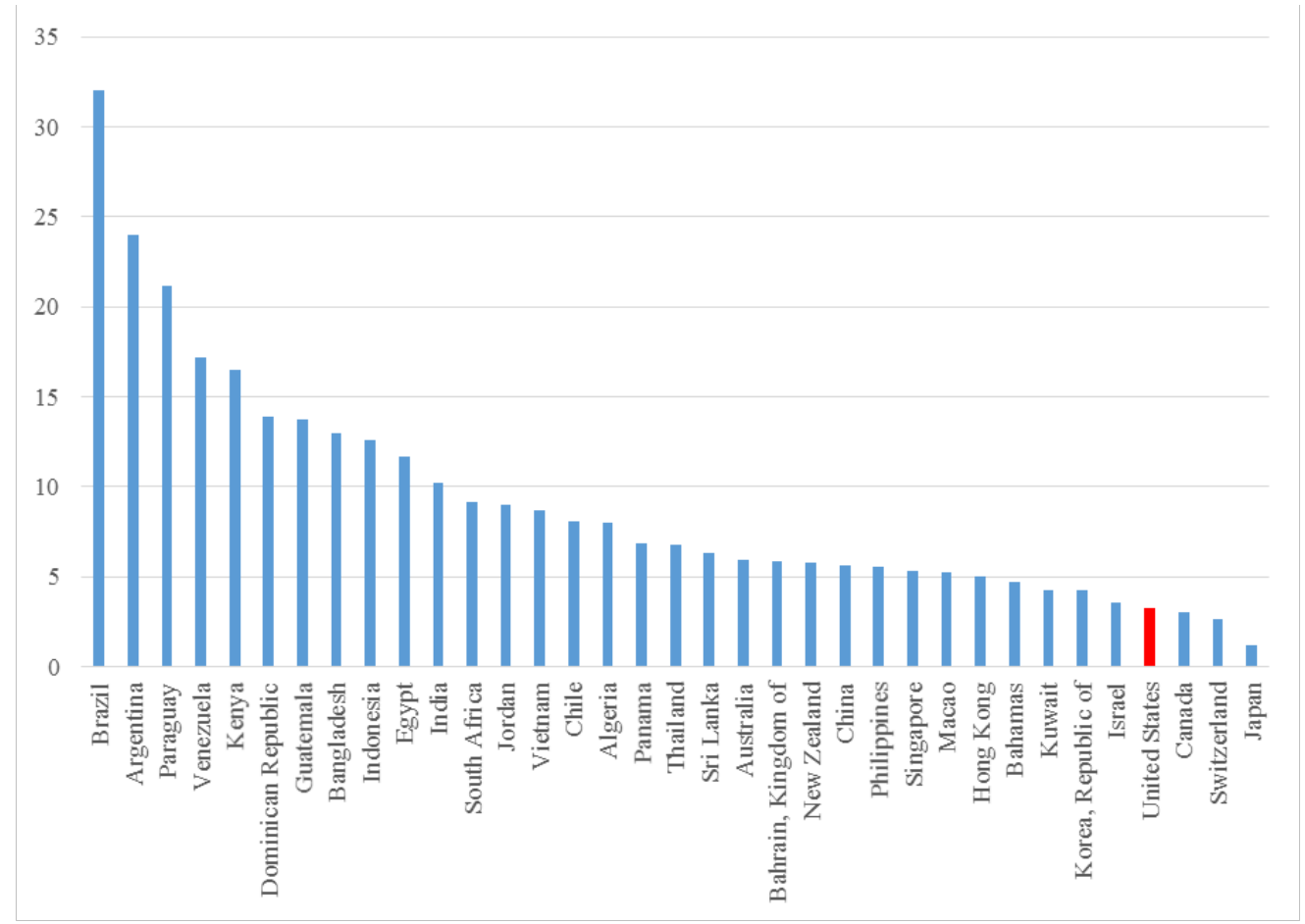

Source: IMF.

Notes: The countries reported in Figure 2.a are those in which US global banks have branches with assets in excess of $\$ 250 \mathrm{~m}$, as available from the FFIEC030 in December 2014. 
Fig. 3.a: Total loans of US-chartered Banks (\$Bn)

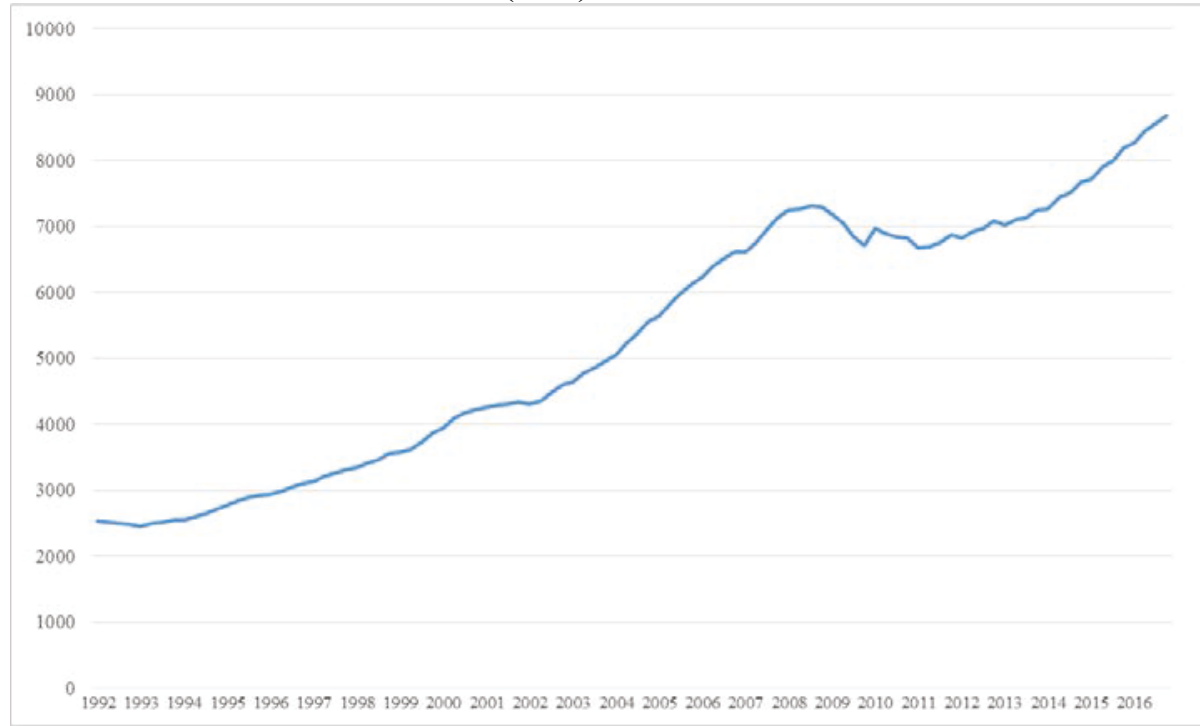

Source: Federal Reserve Bank of St. Louis.

Fig.4.a: Local claims of foreign offices of US banks, \$Bn

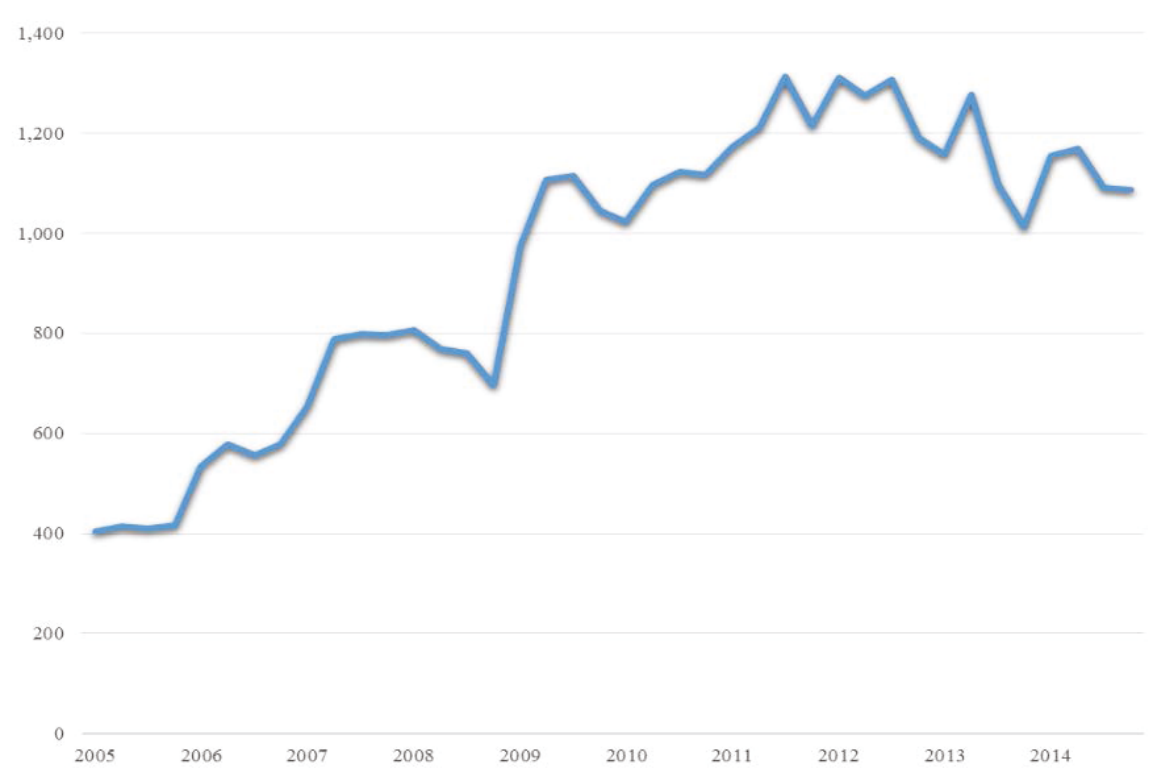

Source: Author's calculation based on FFIEC 009 data

Notes: Fig. 4.a reports local claims of foreign offices (branches and subsidiaries) of US banks located in worldwide. 
Fig. 5.a: Total loans and leases of large and medium sized foreign branches (\$Bn, LHS) and number of large and medium sized foreign branches (RHS)

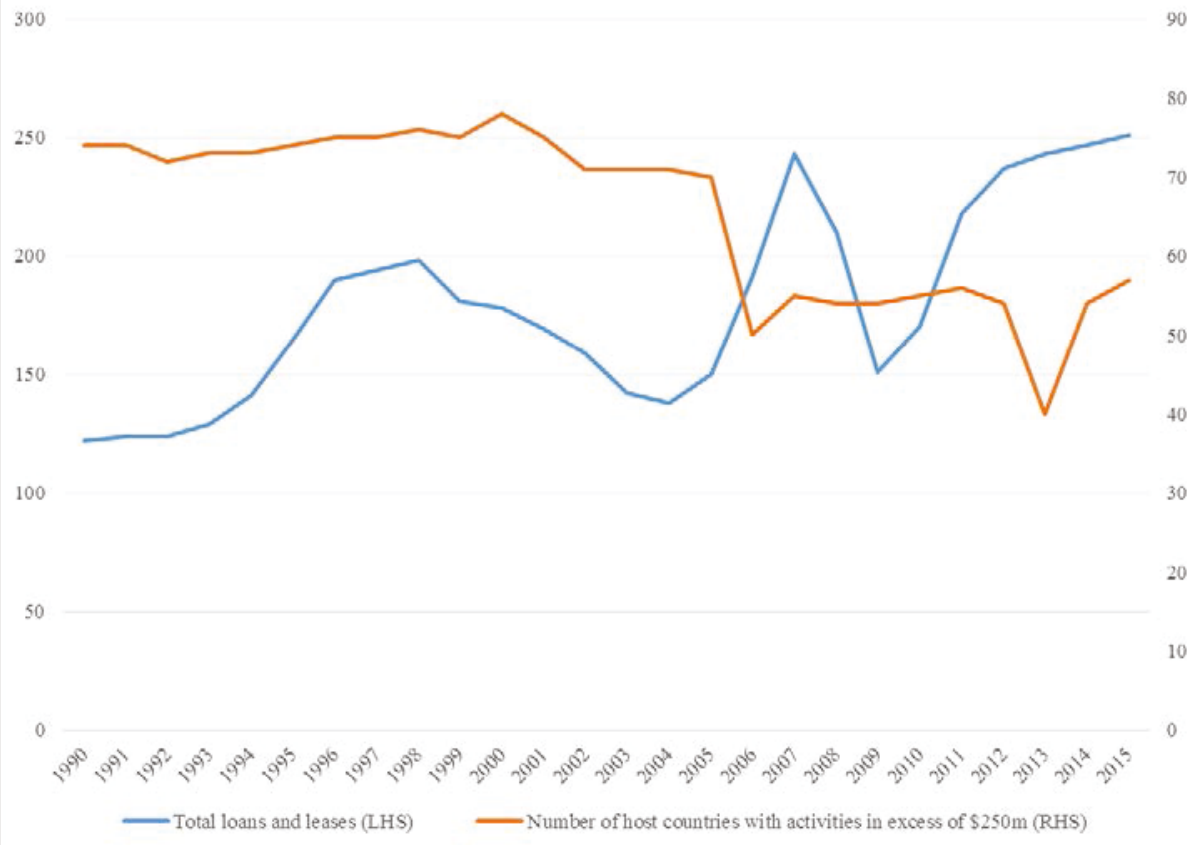

Source: FFIEC030 form.

Fig. 6.a: Net interoffice assets of US global banks, \$m

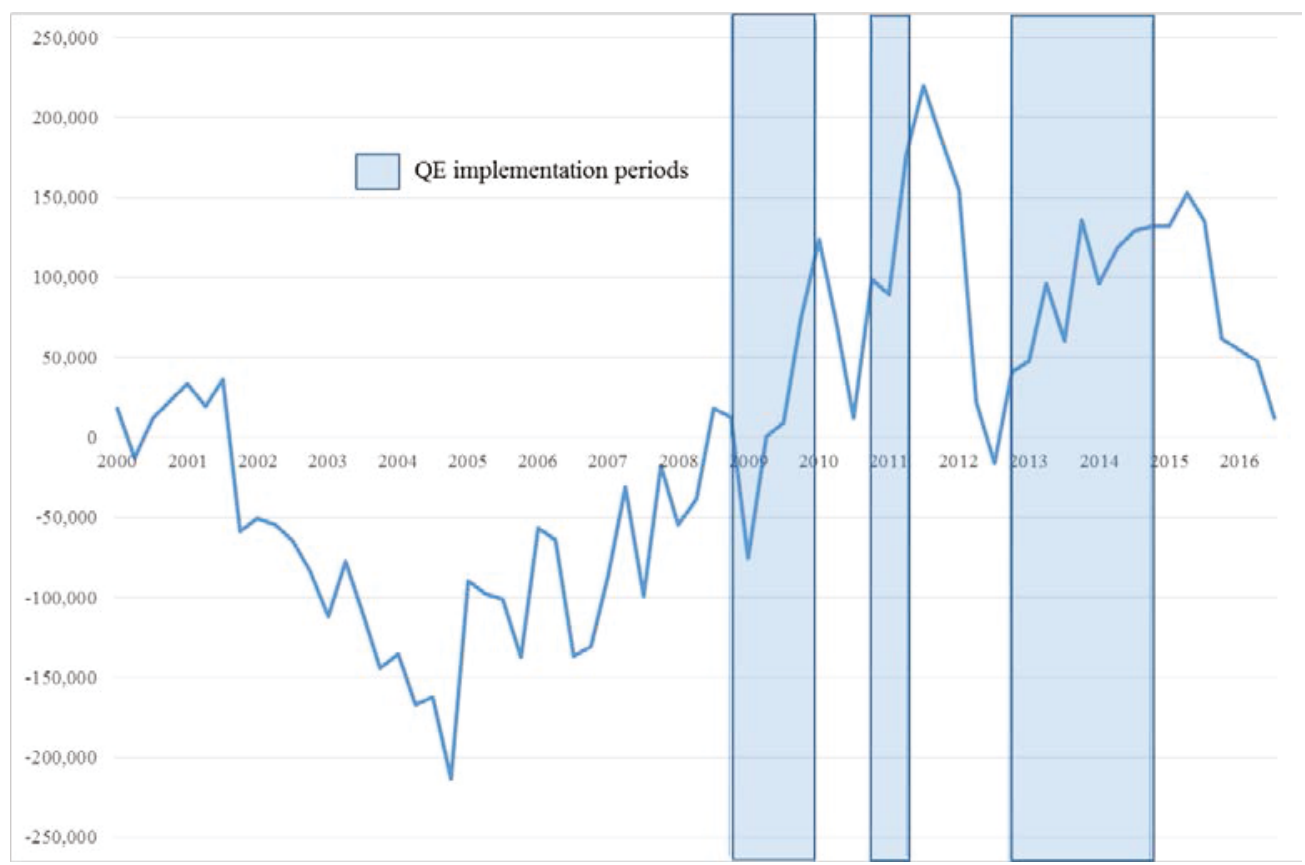

Source: Author's calculation based on BIS Locational Banking Statistics data.

Notes: Fig. 6.a reports net interoffice claims of US banks obtained by subtracting claims from liabilities on related foreign offices. 
Table A.1. GMM estimates, regional sub-samples

\begin{tabular}{|c|c|c|c|c|c|c|c|c|}
\hline $\begin{array}{l}\text { Dependent } \\
\text { variable: }\end{array}$ & \multicolumn{2}{|c|}{ All loans } & \multicolumn{2}{|c|}{ All loans } & \multicolumn{2}{|c|}{ All loans } & \multicolumn{2}{|c|}{ All loans } \\
\hline $\begin{array}{l}\text { Host country } \\
\text { region: }\end{array}$ & \multicolumn{2}{|c|}{$\begin{array}{c}\text { Asia and South } \\
\text { America }\end{array}$} & $\mathrm{Ot}$ & & \multicolumn{2}{|c|}{$\begin{array}{l}\text { Asia and South } \\
\text { America }\end{array}$} & \multicolumn{2}{|c|}{ Other } \\
\hline \multirow[b]{2}{*}{ Variable } & \multicolumn{2}{|c|}{ (a) } & \multicolumn{2}{|c|}{ (b) } & \multicolumn{2}{|l|}{ (c) } & \multicolumn{2}{|c|}{ (d) } \\
\hline & Coefficient & $\begin{array}{l}\text { Std. } \\
\text { Error }\end{array}$ & Coefficient & Std. Error & Coefficient & $\begin{array}{l}\text { Std. } \\
\text { Error }\end{array}$ & Coefficient & $\begin{array}{l}\text { Std. } \\
\text { Error }\end{array}$ \\
\hline DEPNT(-1) & $-0.321 * * *$ & 0.015 & $-0.325^{* * *}$ & 0.055 & 0.026 & 0.036 & $-0.241 * * *$ & 0.029 \\
\hline DEPNT(-2) & $-0.0723 * * *$ & 0.014 & -0.027 & 0.025 & -0.029 & 0.074 & 0.033 & 0.036 \\
\hline GDP(-1) & $0.013 * * *$ & 0.002 & -0.019 & 0.013 & $0.032 * *$ & 0.013 & $0.053 * * *$ & 0.005 \\
\hline $\operatorname{SIZE}(-1)$ & $-0.0678 * * *$ & 0.012 & $-0.144 * * *$ & 0.034 & $-0.282 * * *$ & 0.067 & $-0.135 * * *$ & 0.024 \\
\hline $\operatorname{DIR}(-1)$ & $-0.004 * * *$ & 0.002 & $0.275^{* * *}$ & 0.079 & -0.010 & 0.010 & $0.011^{*}$ & 0.006 \\
\hline US_GDP_G(-1) & 0.662 & 0.491 & $0.054 * * *$ & 0.019 & -0.007 & 0.020 & $0.230 * *$ & 0.070 \\
\hline US_IR_G(-1) & $13.609 * * *$ & 3.662 & 0.034 & 0.105 & 0.126 & 0.128 & $0.033 * * *$ & 0.014 \\
\hline WHOLESALE(-1) & $0.127 * * *$ & 0.036 & $0.534 *$ & 0.292 & -0.672 & 0.469 & $0.470 * * *$ & 0.121 \\
\hline QE & -0.645 & 0.437 & 0.020 & 0.129 & $0.248^{*}$ & 0.130 & $0.146^{* * *}$ & 0.051 \\
\hline RESus(-1) & $-8.687 * * *$ & 1.431 & $0.117 * *$ & 0.050 & $0.341 * *$ & 0.140 & 0.071 & 0.100 \\
\hline RESus(-1)*QE & $13.984 * * *$ & 2.190 & $-1.419 * *$ & 0.671 & -0.528 & 0.852 & -0.025 & 0.538 \\
\hline Sample & \multicolumn{2}{|c|}{$1990 q 4-2015 q 4$} & \multicolumn{2}{|c|}{$1990 q 4-2015 q 4$} & \multicolumn{2}{|c|}{$1990-2015$} & \multicolumn{2}{|c|}{$1990-2015$} \\
\hline Frequency & \multicolumn{2}{|c|}{ Q } & \multicolumn{2}{|c|}{$\mathrm{Q}$} & \multicolumn{2}{|c|}{ A } & \multicolumn{2}{|c|}{ A } \\
\hline Observations & \multicolumn{2}{|c|}{1110} & \multicolumn{2}{|c|}{1135} & \multicolumn{2}{|c|}{250} & \multicolumn{2}{|c|}{183} \\
\hline Sargan-H., p-value & \multicolumn{2}{|c|}{0.660} & \multicolumn{2}{|c|}{0.423} & \multicolumn{2}{|c|}{0.935} & \multicolumn{2}{|c|}{0.328} \\
\hline $\operatorname{AR}(2)$ & \multicolumn{2}{|c|}{0.394} & \multicolumn{2}{|c|}{0.656} & \multicolumn{2}{|c|}{0.402} & \multicolumn{2}{|c|}{0.787} \\
\hline Host-countries & \multicolumn{2}{|c|}{12} & 1 & & 12 & & 9 & \\
\hline
\end{tabular}

Notes: The table reports the estimates of generalized method of moments panel regression using an orthogonal deviation estimator (system estimator). $D E P N T(p)$ variable refers to lagged dependent variable. AR(2) tests are obtained from the GMM differenced estimators. Robust standard errors in parenthesis. $* * *, * *, *$ refer to $1 \%, 5 \%$ and $10 \%$ significance levels, respectively. 
Table A.2. GMM estimates, QE in other countries

\begin{tabular}{|c|c|c|c|c|c|c|}
\hline Dependent variable: & \multicolumn{2}{|c|}{ MORTG } & \multicolumn{2}{|c|}{ COMM } & \multicolumn{2}{|c|}{ INT } \\
\hline Host-countries: & \multicolumn{2}{|c|}{ Core } & \multicolumn{2}{|c|}{ Core } & \multicolumn{2}{|c|}{ Secondary } \\
\hline & \multicolumn{2}{|c|}{ (a) } & \multicolumn{2}{|c|}{ (b) } & \multicolumn{2}{|c|}{ (c) } \\
\hline Variable & Coefficient & Std. Error & Coefficient & Std. Error & Coefficient & Std. Error \\
\hline DEPNT(-1) & $-0.821 * * *$ & 0.009 & $-0.832 * * *$ & 0.018 & $-0.647 * * *$ & 0.027 \\
\hline DEPNT(-2) & $-0.304 * * *$ & 0.011 & $-0.417 * * *$ & 0.020 & $-0.404 * * *$ & 0.026 \\
\hline GDP(-1) & 0.001 & 0.001 & -0.010 & 0.012 & 0.029 & 0.035 \\
\hline SIZE(-1) & $-0.130 * * *$ & 0.014 & $-0.092 * *$ & 0.036 & $-1.124 * * *$ & 0.270 \\
\hline $\operatorname{DIR}(-1)$ & $-0.011 * * *$ & 0.003 & $0.033^{*}$ & 0.017 & $-0.011 * * *$ & 0.002 \\
\hline US_GDP_G(-1) & $-0.306^{* * *}$ & 0.022 & -0.280 & 0.290 & -0.163 & 0.215 \\
\hline US_IR_G(-1) & $1.618^{* * *}$ & 0.121 & 0.469 & 1.178 & -0.149 & 0.495 \\
\hline WHOLESALE(-1) & $0.227 * * *$ & 0.049 & 0.052 & 0.191 & $4.771 * * *$ & 1.057 \\
\hline QE & -0.103 & 0.079 & -0.968 & 1.200 & -0.337 & 0.424 \\
\hline RESus(-1) & $-0.274 * * *$ & 0.091 & -2.643 & 2.490 & $-1.722 * * *$ & 0.626 \\
\hline $\operatorname{RESus}(-1)^{*} \mathrm{QE}$ & $2.8780^{* * *}$ & 1.027 & $8.942 * *$ & 4.663 & $6.408^{*}$ & 3.564 \\
\hline M0_EA(-1) & 1.355 & 1.104 & -0.850 & 5.320 & $1.643 * * *$ & 0.398 \\
\hline M0_UK(-1) & $2.106^{* * *}$ & 0.702 & -2.963 & 6.552 & -2.976 & 2.212 \\
\hline M0 JP(-1) & $2.964 * * *$ & 1.002 & -9.965 & 7.875 & -1.198 & 1.573 \\
\hline Sample & \multicolumn{2}{|c|}{$1990 q 4-2015 q 4$} & \multicolumn{2}{|c|}{$1990 q 4-2015 q 4$} & \multicolumn{2}{|c|}{$1990 q 4-2015 q 4$} \\
\hline Frequency & \multicolumn{2}{|c|}{ Q } & \multicolumn{2}{|c|}{$\mathrm{Q}$} & \multicolumn{2}{|c|}{ A } \\
\hline Observations & \multicolumn{2}{|c|}{1379} & \multicolumn{2}{|c|}{1980} & \multicolumn{2}{|c|}{78} \\
\hline Sargan-H., p-value & \multicolumn{2}{|c|}{0.964} & \multicolumn{2}{|c|}{0.746} & \multicolumn{2}{|c|}{0.426} \\
\hline $\operatorname{AR}(2)$ & \multicolumn{2}{|c|}{0.520} & \multicolumn{2}{|c|}{0.904} & \multicolumn{2}{|c|}{0.706} \\
\hline Host-countries & \multicolumn{2}{|c|}{22} & \multicolumn{2}{|c|}{23} & \multicolumn{2}{|c|}{12} \\
\hline
\end{tabular}


Table A.3

\begin{tabular}{|c|c|c|c|c|c|c|c|c|c|c|c|c|}
\hline \multirow[t]{4}{*}{ Dependent variable: } & \multicolumn{2}{|c|}{ All loans } & \multicolumn{2}{|c|}{ All loans } & \multicolumn{2}{|c|}{ All loans } & \multicolumn{2}{|c|}{ All loans } & \multicolumn{2}{|c|}{ All loans } & \multicolumn{2}{|c|}{ All loans } \\
\hline & Coefficient & $\begin{array}{c}\text { Std. } \\
\text { Error }\end{array}$ & Coefficient & $\begin{array}{c}\text { Std. } \\
\text { Error }\end{array}$ & Coefficient & $\begin{array}{c}\text { Std. } \\
\text { Error }\end{array}$ & Coefficient & $\begin{array}{c}\text { Std. } \\
\text { Error }\end{array}$ & Coefficient & $\begin{array}{c}\text { Std. } \\
\text { Error }\end{array}$ & Coefficient & $\begin{array}{c}\text { Std. } \\
\text { Error }\end{array}$ \\
\hline & \multicolumn{2}{|c|}{ (a) } & \multicolumn{2}{|c|}{ (b) } & \multicolumn{2}{|l|}{ (c) } & \multicolumn{2}{|c|}{ (d) } & \multicolumn{2}{|c|}{ (e) } & \multicolumn{2}{|l|}{ (f) } \\
\hline & $-0.311 * * *$ & 0.021 & $-0.315^{* * *}$ & 0.022 & $-0.394 * * *$ & 0.029 & 0.010 & 0.053 & 0.024 & 0.051 & 0.020 & 0.035 \\
\hline DEPNT(-2) & $-0.071 * * *$ & 0.017 & $-0.077 * * *$ & 0.018 & $-0.086 * * *$ & 0.017 & $-0.171 * *$ & 0.067 & $-0.126^{* *}$ & 0.051 & $-0.172 * * *$ & 0.038 \\
\hline GDP(-1) & $0.011 * * *$ & 0.003 & $0.012 * * *$ & 0.003 & $0.013 * *$ & 0.005 & $0.029 * * *$ & 0.010 & $0.028^{* * *}$ & 0.005 & $0.020^{* * *}$ & 0.003 \\
\hline $\operatorname{SIZE}(-1)$ & $-0.065^{* * *}$ & 0.013 & $-0.057 * * *$ & 0.015 & $-0.062 * * *$ & 0.017 & $-0.188 * * *$ & 0.043 & $-0.165^{* * *}$ & 0.039 & $-0.102^{* * *}$ & 0.028 \\
\hline $\operatorname{DIR}(-1)$ & $-0.005^{* * *}$ & 0.002 & $-0.004 * * *$ & 0.002 & $-0.003 * * *$ & 0.001 & $-0.013 * *$ & 0.006 & $-0.015 * * *$ & 0.005 & -0.001 & 0.001 \\
\hline US_GDP_G(-1) & $-0.245^{*}$ & 0.129 & -0.047 & 0.158 & $1.414^{* * *}$ & 0.305 & -0.007 & 0.009 & 0.015 & 0.037 & 0.007 & 0.008 \\
\hline US_IR_G(-1) & $3.807 * * *$ & 0.317 & $3.539 * * *$ & 0.117 & $3.516^{* * *}$ & 0.160 & $0.129^{* *}$ & 0.061 & 0.105 & 0.071 & $0.115^{* * *}$ & 0.035 \\
\hline WHOLESALE(-1) & $0.171^{* *}$ & 0.066 & $0.178^{* *}$ & 0.076 & $0.188^{*}$ & 0.104 & -0.106 & 0.259 & $-0.373^{*}$ & 0.212 & $-0.341 * * *$ & 0.126 \\
\hline RESus(-1) & $0.876^{*}$ & 0.463 & $0.832 *$ & 0.456 & $-2.719 * * *$ & 0.732 & -0.127 & 0.468 & $0.207^{* *}$ & 0.093 & 0.069 & 0.048 \\
\hline QE1 & $-14.008 * *$ & 6.029 & & & & & $-0.169^{*}$ & 0.096 & & & & \\
\hline QE2_1 & & & $-15.334^{* *}$ & 6.232 & & & & & 0.196 & 0.136 & & \\
\hline QE2_2 & & & & & $2.232 * * *$ & 0.747 & & & & & $-0.077^{* *}$ & 0.032 \\
\hline $\operatorname{RES}_{\mathrm{us}}(-1)^{*} \mathrm{QE} 1$ & 12.438 & 12.541 & & & & & 0.424 & 0.478 & & & & \\
\hline $\mathrm{RES}_{\text {us }}(-1)^{*} \mathrm{QE} 2 \_1$ & & & 220.003 & 181.874 & & & & & 0.025 & 4.413 & & \\
\hline RES us $(-1) * \mathrm{QE} 2 \quad 2$ & & & & & $8.441 * * *$ & 2.783 & & & & & 0.229 & 0.299 \\
\hline Sample & $1990 \mathrm{q} 4-2$ & $15 \mathrm{q} 4$ & $1990 \mathrm{q} 4$ & $15 \mathrm{q} 4$ & $1990 \mathrm{q} 4-2$ & $5 \mathrm{q} 4$ & $1990-2$ & & $1990-2$ & & $1990-2$ & \\
\hline Frequency & Q & & ( & & Q & & A & & A & & A & \\
\hline Observations & 205 & & 20 & & 2059 & & 433 & & 43 & & 433 & \\
\hline Sargan-H., p-value & 0.11 & & 0.1 & & 0.19 & & 0.51 & & 0.67 & & 0.49 & \\
\hline $\operatorname{AR}(2)$ & 0.55 & & 0.8 & & 0.77 & & 0.11 & & 0.10 & & 0.18 & \\
\hline Host-countries & 23 & & 2 & & 23 & & 21 & & 21 & & 21 & \\
\hline
\end{tabular}

Notes: The table reports the estimates of generalized method of moments panel regression using an orthogonal deviation estimator (system estimator). $D E P N T(p)$ variable refers to lagged dependent variable. AR(2) tests are obtained from the GMM differenced estimators. Robust standard errors in parenthesis. $* * *, * * *$ refer to $1 \%, 5 \%$ and $10 \%$ significance levels, respectively. 
Table A.4. GMM estimates, three QE waves

\begin{tabular}{|c|c|c|c|c|c|c|}
\hline \multirow[t]{2}{*}{ Dependent variable: } & \multicolumn{2}{|c|}{ INT } & \multicolumn{2}{|c|}{ INT } & \multicolumn{2}{|c|}{ INT } \\
\hline & Coefficient & Std. Error & Coefficient & Std. Error & Coefficient & Std. Error \\
\hline & \multicolumn{2}{|c|}{ (a) } & \multicolumn{2}{|c|}{ (b) } & \multicolumn{2}{|c|}{ (c) } \\
\hline DEPNT(-1) & $-0.638 * * *$ & 0.077 & $-0.812 * * *$ & 0.040 & $-0.801 * * *$ & 0.037 \\
\hline DEPNT(-2) & $-0.340 * * *$ & 0.061 & $-0.431 * * *$ & 0.034 & $-0.425 * * *$ & 0.030 \\
\hline $\operatorname{SIZE}(-1)$ & $-1.612 * * *$ & 0.190 & $-0.853 * * *$ & 0.107 & $-1.354 * * *$ & 0.101 \\
\hline GDP(-1) & $0.065^{* *}$ & 0.030 & $0.114 * * *$ & 0.004 & $0.081^{* * *}$ & 0.011 \\
\hline $\operatorname{DIR}(-1)$ & -0.002 & 0.023 & $-0.009 * * *$ & 0.002 & $-0.011 * * *$ & 0.004 \\
\hline US_GDP_G(-1) & $0.405^{* * *}$ & 0.080 & $0.113^{* * *}$ & 0.037 & $0.364 * * *$ & 0.036 \\
\hline US_IR_G(-1) & $-0.606^{* *}$ & 0.288 & $-0.717 * * *$ & 0.147 & $-0.967 * * *$ & 0.148 \\
\hline WHOLESALE(-1) & $9.050 * * *$ & 1.536 & $5.632 * * *$ & 0.315 & $6.917 * * *$ & 0.722 \\
\hline RESus(-1) & -1.341 & 3.862 & -0.553 & 0.358 & 0.113 & 0.391 \\
\hline QE1 & 0.448 & 1.015 & & & & \\
\hline QE2_1 & & & $-1.926 * * *$ & 0.141 & & \\
\hline QE2_2 & & & & & $0.624 * *$ & 0.282 \\
\hline $\operatorname{RESus}(-1)^{*} \mathrm{QE} 1$ & 0.814 & 4.656 & & & & \\
\hline RESus(-1)*QE2_1 & & & -2.238 & 7.880 & & \\
\hline $\operatorname{RESus}(-1)^{*} \mathrm{QE} 2 \_2$ & & & & & $2.774 * * *$ & 0.714 \\
\hline Sample & \multicolumn{2}{|c|}{$1990-2015$} & \multicolumn{2}{|c|}{$1990-2016$} & \multicolumn{2}{|c|}{$1990-2017$} \\
\hline Frequency & \multicolumn{2}{|c|}{ A } & \multicolumn{2}{|c|}{ A } & \multicolumn{2}{|c|}{ A } \\
\hline Observations & \multicolumn{2}{|c|}{78} & \multicolumn{2}{|c|}{78} & \multicolumn{2}{|c|}{78} \\
\hline Sargan-H., p-value & \multicolumn{2}{|c|}{0.446} & \multicolumn{2}{|c|}{0.814} & \multicolumn{2}{|c|}{0.513} \\
\hline $\operatorname{AR}(2)$ & \multicolumn{2}{|c|}{0.532} & \multicolumn{2}{|c|}{0.108} & \multicolumn{2}{|c|}{0.100} \\
\hline Host-countries & \multicolumn{2}{|c|}{12} & \multicolumn{2}{|c|}{12} & \multicolumn{2}{|c|}{12} \\
\hline
\end{tabular}

Notes: The table reports the estimates of generalized method of moments panel regression using an orthogonal deviation estimator (system estimator). $D E P N T(p)$ variable refers to lagged dependent variable. AR(2) tests are obtained from the GMM differenced estimators. Robust standard errors in parenthesis. $* * *, * *, *$ refer to $1 \%, 5 \%$ and $10 \%$ significance levels, respectively. 